\title{
DiOTtos
}

Revista de Comunicación Digital

\section{Estudio exploratorio de las estrategias de encuadre discursivo en memes humorísticos publicados en Twitter durante las elecciones generales de noviembre de 2019 celebradas en España}

\section{Exploratory study of discursive framing strategies in humorous memes published on Twitter during the November 2019 general elections in Spain}

\section{Ana Mancera Rueda \\ anamancera@us.es \\ Universidad de Sevilla}

\section{Resumen}

La presente investigación se basa en el análisis de un corpus de 115 memes humorísticos difundidos en la red social Twitter, durante las elecciones generales celebradas en España en noviembre de 2019. Para su recopilación se han consultado los tuits publicados haciendo uso de los hashtags que se convirtieron en trending topic, en el transcurso de la campaña electoral que tuvo lugar entre el 1 y el 10 de noviembre de 2019. En ellos hemos podido identificar los principales rasgos que caracterizan al discurso pseudopolítico y determinadas estrategias de encuadre discursivo utilizadas para movilizar el voto y orientar cognitivamente los mensajes.

\section{Palabras clave}

memes, estrategias de encuadre, redes sociales, comunicación política

\begin{abstract}
This research is based on the analysis of a corpus of 115 humorous memes published in the social network Twitter, during the general elections held in Spain in November 2019. The tweets published have been compiled using the hashtags that became trending topic, during the electoral campaign that took place between November 1 and 10, 2019. In this type of memes, we have been able to identify the main features that characterize the pseudo-political discourse and certain discursive framing strategies used to mobilize the vote and cognitively orient messages.
\end{abstract}

\section{Keywords}

memes, framing strategies, social networks, political communication.

Esta contribución se inscribe en el marco del Proyecto de Investigación PRODISNET-02: Procesos discursivos en internet: desplazamientos enunciativos y efectos hiperbólicos en el discurso político (Ref. RTI2018-093523-B-I00), del Ministerio de Ciencia, Innovación y Universidades. Agradecemos a los evaluadores anónimos de la revista Dígitos y a las coordinadoras del monográfico en el que esta ha sido publicada sus valiosas sugerencias.

Cómo citar este artículo:

Mancera Rueda, A. (2020). Estudio exploratorio de las estrategias de encuadre discursivo en memes humorísticos publicados en Twitter durante las elecciones generales de noviembre de 2019 celebradas en España. Dígitos. Revista de Comunicación Digital, 6: 197-217. DOI: 10.7203/rd.v1i6.180 
Estudio exploratorio de las estrategias de encuadre discursivo en memes humorísticos publicados en Twitter durante las elecciones generales de noviembre de 2019 celebradas en España

\section{Introducción}

El 10 de noviembre de 2019 los españoles estaban llamados a las urnas por tercera vez en un mismo año, tras haber acudido a votar en las elecciones generales de abril y en las autonómicas y municipales de mayo. Desde diciembre de 2015, habían sido convocados cuatro veces en cuatro años -diciembre de 2015, junio de 2016, abril y noviembre de 2019- para elegir a sus representantes en el parlamento, lo que hacía prever una elevada tasa de abstención que, según el "Macrobarómetro de octubre de 2019. Preelectoral Elecciones Generales 2019" (Centro de Investigaciones Sociológicas [CIS], 2019) difundido pocos días antes de la cita electoral del 10N, se situaba en torno al $11,8 \%$. De acuerdo con dicho macrobarómetro, las redes sociales constituyen el segundo medio al que recurren los ciudadanos para "informarse sobre los asuntos políticos y de campaña electoral". En concreto, el 12,8 \% de los encuestados afirmó decantarse por este procedimiento, un porcentaje solo superado por el de los ciudadanos que recurrían a la televisión -el 61,3\%-.

Twitter es considerada la red social "más politizada", según los resultados de un estudio desarrollado por la agencia de marketing digital Elogia (2019) -así lo afirmó un 60 \% de los encuestados, frente al $27 \%$, que se decantaba por Facebook-. Pese a que el número de usuarios de Twitter -en torno a los 320 millones en todo el mundo; 4,4 millones en España (The Social Media Family, 2020)1- es mucho menor que el de sus competidoras -alrededor de 2.200 millones en el caso de Facebook, 2.000 en el de YouTube y 1.000 en el de Instagram-, su grado de influencia en la política y en los medios de comunicación es muy superior. Especialmente, a raíz de la campaña del presidente norteamericano Barack Obama en 2008 (Feld y Wilcox, 2008; Rubio, 2009; Pérez Barber, 2010; Mancera y Pano, 2013). Pero no solo los políticos se sirven de esta red social para tratar de movilizar a sus votantes potenciales. También otros usuarios de Twitter formulan un "discurso pseudopolítico que se desarrolla junto al propiamente político, en sus márgenes, motivado parcialmente por él" (Gallardo y Enguix, 2016: 101), y que se caracteriza por la personalización de la política -focalizada en el líder-, la desideologización de la ciudadanía -con el triunfo de la emoción sobre el argumento lógico-, y la "espectacularización" de la información difundida en los medios -entendida como el desplazamiento del debate deliberativo sobre el bien común "por un discurso ensimismado y teatralizador, autocomplaciente y preocupado por la puesta en escena" (Gallardo y Enguix, 2016: 100)-.

El propósito de esta investigación es analizar cómo se difunde en Twitter tal discurso pseudopolítico, en el transcurso de unas elecciones generales, a través de los memes

1 Según los datos de dicho estudio, Facebook e Instagram son las redes sociales más utilizadas por los españoles, con 22 y 16 millones de usuarios, respectivamente. Hay que tener en cuenta que no toda la ciudadanía participa por igual en las redes sociales. En España, 25,5 millones de usuarios cuentan con presencia en alguna de estas plataformas, el equivalente al $85 \%$ de los internautas entre 16 y 65 años. En 2019 las ciudades españolas con mayor número de usuarios de Twitter fueron Sevilla $(21,88 \%$ ), Valencia $(21,70 \%)$ y Barcelona $(21,61 \%)$. 
"viralizados" por los usuarios de esta red social, ya sea para movilizar el voto, ya sea, simplemente, para mostrar su distanciamiento hacia un determinado candidato, haciendo uso del humor como mecanismo paródico.

\section{Estado de la cuestión}

El término "meme" fue acuñado por Richard Dawkins en su monografía El gen egoísta (1979). De acuerdo con este biólogo evolutivo, el meme es una "unidad de transmisión cultural o de imitación", es decir, una idea o comportamiento que se expande de persona a persona en el seno de una determinada cultura, de manera similar a como suelen hacerlo los genes y los virus. Como explica el propio Dawkins, "meme" procede de la palabra griega mimema, que significa "algo que se imita". Existen dos tipos de información: la transmitida a través de los genes, que se encuentra en el ADN y es hereditaria; y la información cultural, que es procesada por el cerebro y puede ser adoptada y modificada por cualquier persona a través de un proceso cognitivo, tras serle transmitida por otro individuo. A esta última tipología pertenecen los memes, que cumplen el mismo propósito que los genes en la vertiente biológica, pero como transmisores de la herencia cultural.

Como explicamos más detenidamente en Mancera y Pano (en prensa), Internet se "apropió" del término de Dawkins en los años noventa, cuando comenzó a utilizarlo para hacer alusión a una serie de vídeos o imágenes acompañadas por un breve texto -normalmente con una tipografía destacada y de color blanco- que suele cambiar en función de cuál sea el significado que su creador desee otorgarle en cada momento. En diversas entrevistas, el propio Dawkins ha mostrado su conformidad con el uso de la palabra meme para referirse a este tipo de contenidos, ya que se transmiten en blogs, páginas web y redes sociales, de manera viral (Dynel, 2016).

Algunos autores los denominan “imemes” (Vélez, 2015) y, según Marino (2015), estos se caracterizan por: su carácter textual; la presencia en ellos de sustancias expresivas sincréticas, derivadas de un proceso de intervención sobre textos preexistentes de acuerdo con reglas de pertinencia; y están dotados de una eficacia colectivamente asignada y reconocida, gracias a su intencionalidad lúdica, a la anonimidad de su creador y a sus modalidades de difusión repetitivas, apropiativas y participativas.

De ahí el interés de este tipo de corpus para el desarrollo de estudios de carácter discursivo centrados en el análisis de los memes como producto multimedia. Véanse, por ejemplo, los trabajos pioneros de Blackmore (1998, 1999, 2001), los estudios de Milner (2012), Miltner (2014), Gal, Shifman y Kampf (2015) y de Kanai (2016) sobre la construcción de una identidad colectiva, o las investigaciones de Forceville (2014), Forceville y Clark (2014) y Yus (2018, 2019, en prensa), basadas en la Teoría de la Relevancia. De acuerdo con Siri (2016: 20), "la principal razón para sostener que los memes de internet constituyen un género dentro de las múltiples producciones que los usuarios comparten online es su reconocimiento como tal por parte de los 'nativos'". De hecho, existen sitios web dedicados a recolectarlos, catalogarlos y estudiarlos, a modo de "censos sistemáticos" (Steimberg, 2013: 71) -por ejemplo, Know your meme-.

Según ha puesto de manifiesto Shifman (2013), los memes difundidos a través de internet se han convertido en un código de comunicación continuo, cotidiano y universal. Estos pueden ser de distinta temática, si bien en el presente artículo nos centraremos únicamente en aquellos dotados de carácter humorístico, los cuales "se perciben como 'píldoras de bienestar', en tanto son breves estímulos cómicos que 
pretenden provocar la risa" (Ballesteros, 2016: 23), y con los que se logra relativizar y poner distancia de los conflictos que acontecen en la escena política (Yus, en prensa). Así, "una de las tradiciones visuales donde el meme encuentra continuidad es la de la sátira política" (Winckler, 2019: 3). De hecho, la relación entre cultura popular y política es de larga data, hasta el punto de que Pestarino y Winckler (2018) llegan a considerar que el actual activismo de las redes sociales bebe de la tradición de ciertos grabados que circulaban en Europa durante los conflictos bélicos y las guerras de religión que acontecieron en los siglos XVI y XVII, como armas ideológicas y propagandísticas "con un potencial inédito de infiltración social" (Burucúa, 2007: 61).

El marco teórico en el que se fundamenta la presente investigación es el desarrollado por Gallardo (2014), que estudia las categorías pragmáticas de acuerdo con tres niveles -en consonancia con la descripción clásica de Morris (1985)-: el textual, en el que se engloban los principios básicos de coherencia y cohesión; el enunciativo, que abarca aspectos como los actos de habla, las implicaturas y la deixis mostrativa, como manifestaciones de la intención comunicativa del sujeto de la enunciación; y el interactivo, determinado por la inclusión del receptor en el discurso. Desde esta perspectiva se considera "el encuadre discursivo como la estrategia de diseño global de un texto, que responde a la intención comunicativa del emisor" (Gallardo, en prensa). En virtud de ella, el sujeto enunciador escoge -aunque a veces no de un modo consciente- todos los elementos lingüísticos que contribuyen a orientar cognitivamente la interpretación de un mensaje.

\section{Descripción del corpus y consideraciones metodológicas}

La presente investigación se basa en el análisis de un corpus de 115 memes humorísticos publicados en la red social Twitter, durante las elecciones generales celebradas en España en noviembre de 2019. Por lo tanto, el periodo de tiempo analizado abarca desde el 1 hasta el 10 de noviembre de 2019, fecha de celebración de los comicios -hay que tener en cuenta que, en dicha ocasión, el periodo de campaña electoral contó con una duración de ocho días en lugar de los quince habituales-. Para la recopilación del corpus se han consultado los mensajes publicados haciendo uso de los hashtags que se convirtieron en trending topic -tendencia global, es decir, tema que se encuentra entre los más tuiteados en un determinado momento-.

El hashtag (HT) o etiqueta es una convención textual basada en el empleo del signo \#, seguido de una palabra o un sintagma cuyas lexías se presentan generalmente fusionadas. Esta permite no solo ahorrar espacio para decir más con menos, sino también marcar el tema del tuit como una forma de metadato explícito en el mensaje, que puede aparecer integrado en la estructura sintáctica del enunciado en el que se inserta, o bien en los márgenes, al inicio o al final del mensaje (Mancera y Pano, 2015). Las etiquetas cumplen una función discursiva, ya que permiten recopilar los distintos tuits sobre un mismo tema, recapitular ideas, "tejer conversaciones alrededor de un tema determinado e incluso entrar espontáneamente en conversaciones ajenas con el simple uso de su misma palabra clave" (Lara, 2012). Por lo tanto, constituyen un elemento fundamental para conocer cuáles fueron los aspectos que suscitaron mayor hilaridad entre la opinión pública a lo largo de dicha campaña electoral. Con este fin se analizaron las "conversaciones tejidas" en torno a los siguientes hashtags: \#debatea5RTVE,\#Debatea7RTVE,\#DebateElectoral,\#Elecciones10N,\#Elecciones10NL6, \#EleccionesGenerales, \#eleccionesgenerales10N, \#EleccionesNoviembre2019, \#EspecialEleccionesRTVE, \#JornadaDeReflexion, \#L6NPedroSanchez, \#VotaPorFavor, \#YoVoto, \#10N y \#10NEMT. 


\section{Análisis y resultados}

Para caracterizar este tipo de textos de acuerdo con el marco teórico llevado a cabo por Gallardo (2014), nos centraremos primero en el análisis del encuadre textual, que tiene que ver con el paratexto, la estructura textual predominante y la organización temática de los contenidos. Algunos de los memes de nuestro corpus responden a la categoría de lo que en la clasificación de Milner (2012) se considera una "imagen estable" -stable image-, es decir, aquella que no ha experimentado ningún tipo de transformación, como podemos ver en el siguiente ejemplo (Fig. 1), basado en una de las escenas de Los Simpson, sobre la que se ha superpuesto la etiqueta propagandística \#YoVotoVox -a modo de discurso referido que se atribuye a Homer Simpson- y un enunciado reactivo -la réplica de su esposa-. De esta manera se equipara a los votantes de Vox con un personaje televisivo conocido por sus escasas luces. En este caso nos encontramos ante un meme basado en una "imagen macro", sobre la que se inserta texto haciendo uso de la tipografía "Impact"2:

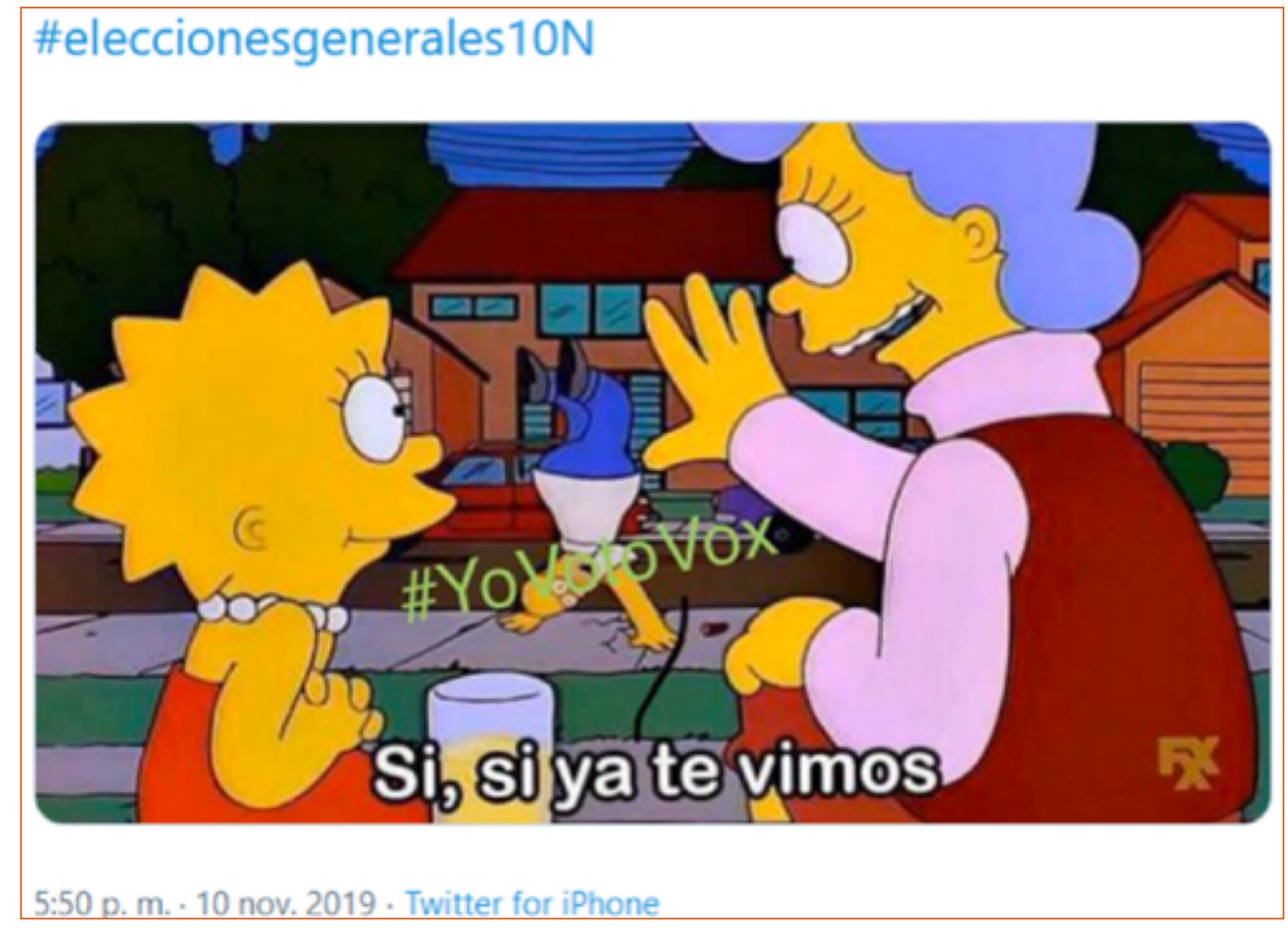

Figura 1

Como explica Ballesteros (2016: 26) acerca de este tipo de meme: “De manera general, su composición combina una imagen -fotografía o dibujo-, sobre la que se inserta un texto, aunque de forma menos frecuente se pueden también encontrar memes exclusivamente textuales o visuales". Por otra parte, Milner (2012) identifica también en su clasificación los memes basados en la mezcla de distintas imágenes -remixed image-, como las utilizadas en la Figura 2 para equiparar fotografías del futbolista Sergio Ramos en diferentes momentos de su vida, con los estereotipos sobre los votantes de diversos partidos (figura 2).

Sin embargo, en la mayor parte de los ejemplos que conforman nuestro corpus, el humor se produce no exclusivamente a partir de la imagen, sino de la vinculación

2 A pesar de que ninguno de los mensajes aquí recogidos procede de perfiles de acceso restringido, siguiendo las directrices de las coordinadoras de este monográfico, se han eliminado los enlaces a todos los tuits, así como los avatares, nombres de perfil y menciones a otros usuarios. 
Sergio Ramos's political option chart.
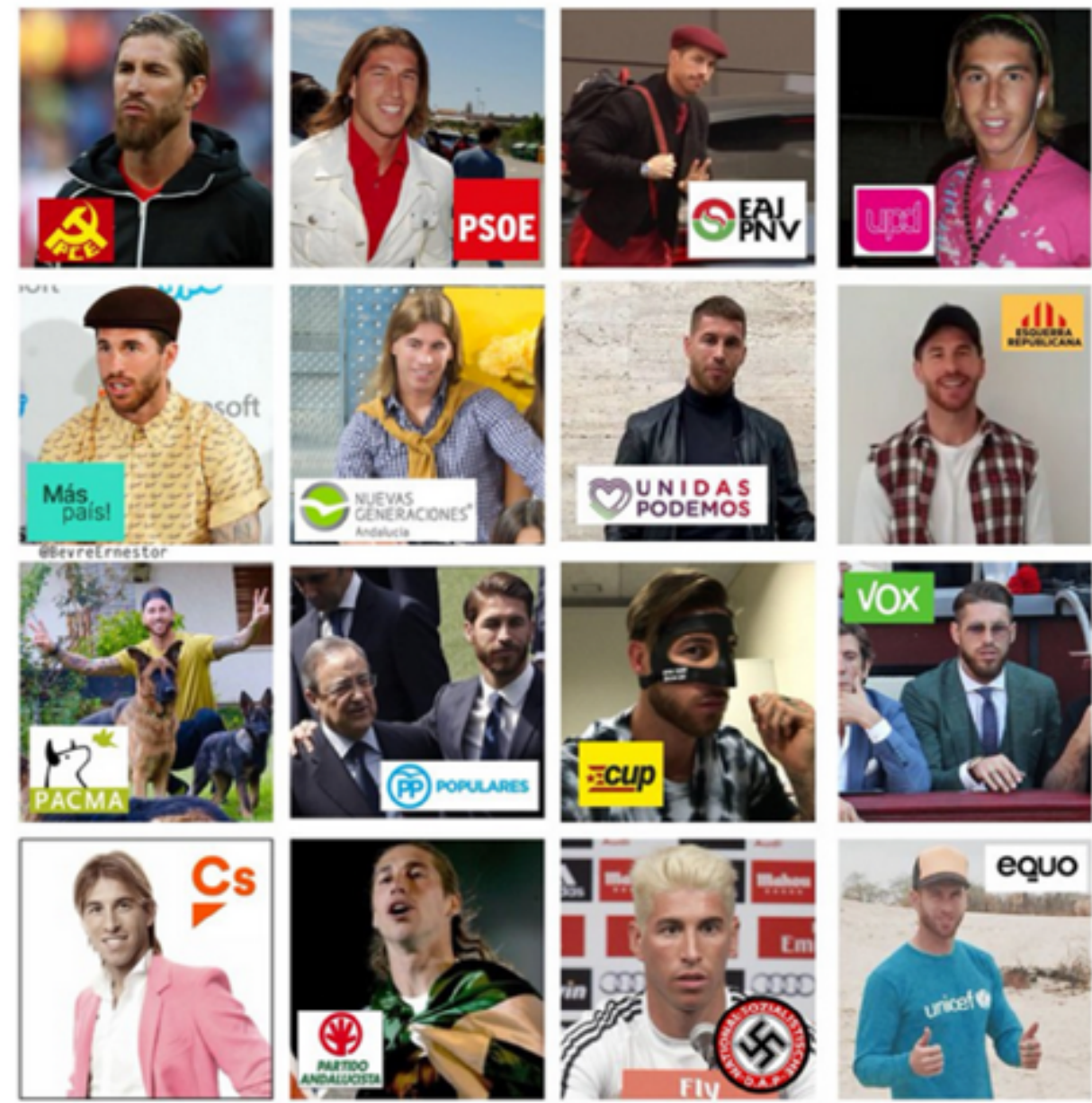

$5.21120: 18-7$ nov. 2019

Figura 2

entre esta y el texto del tuit que la acompaña. Tal imagen puede ser un gif audiovisual en movimiento -cfr. Shifman (2012) y Wiggins y Bowers (2015) para un análisis más detallado de este tipo de memes de carácter dinámico-, con el que se reproduce una y otra vez un instante de una película, como ocurre en la Figura 3, en la que, a modo de respuesta a unas afirmaciones formuladas en el transcurso de un debate por Iván Espinosa de los Monteros, representante de Vox -"Los conservadores somos los que conservamos el medio ambiente"-, se muestra al actor Jack Nicholson al mover los brazos haciendo un gesto de negación enfática (figura 3).

Pero también puede tratarse de una fotografía que remite a algún evento que adquirió cierta relevancia en la campaña electoral y que permite identificar al referente del texto. Por ejemplo, la imagen de Albert Rivera acariciando a un cachorro en la Figura 4 evoca en el lector del siguiente tuit las declaraciones del líder de Ciudadanos al presentar al animal como su "arma secreta" para ganar uno de los debates electorales y afirmar de él: "Aún huele a leche, es un bebito. Quien me ataque en el debate, ya sabe, tendrá que enfrentarse a Lucas" (20 Minutos, 2019). Adviértase aquí una muestra de lo que Gallardo y Enguix (2016: 101) identifican como "discurso pseudopolítico", en el que se produce una banalización de la campaña electoral. Aunque tales palabras no se reproducen en el mensaje, la fotografía es la que permite recordarlas y conferir sentido al texto, en el 


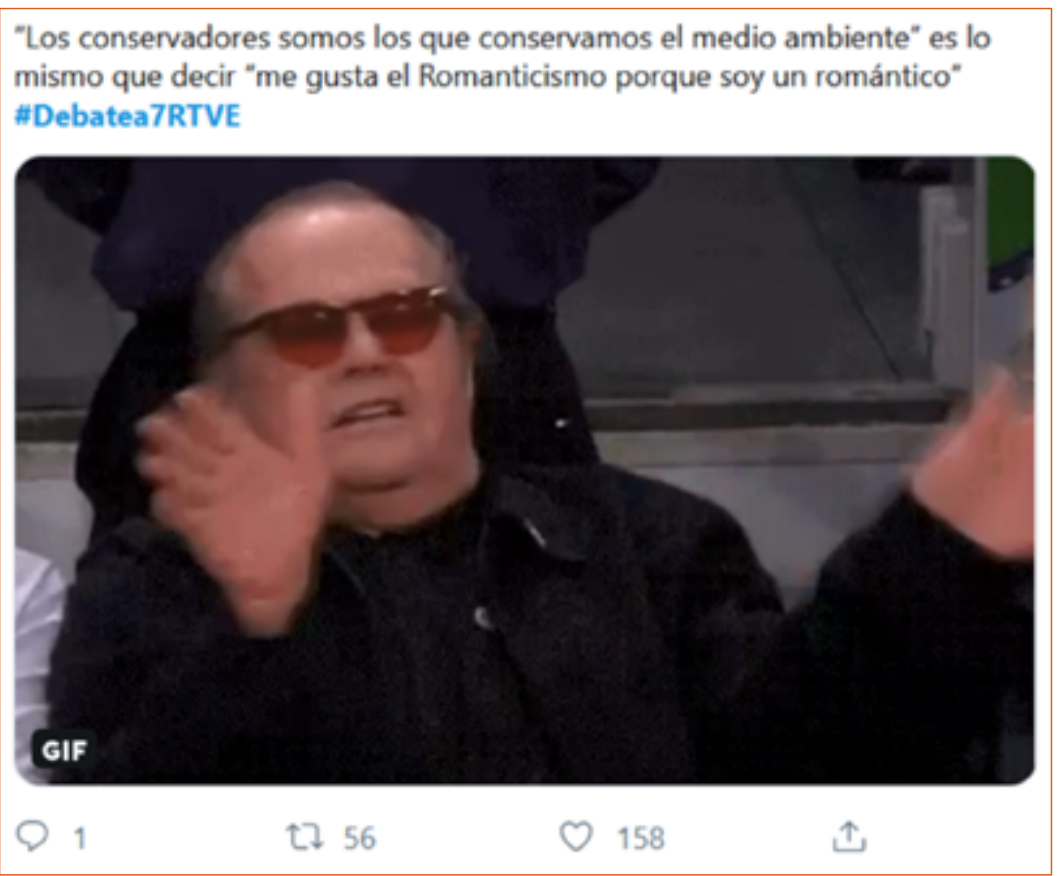

Figura 3

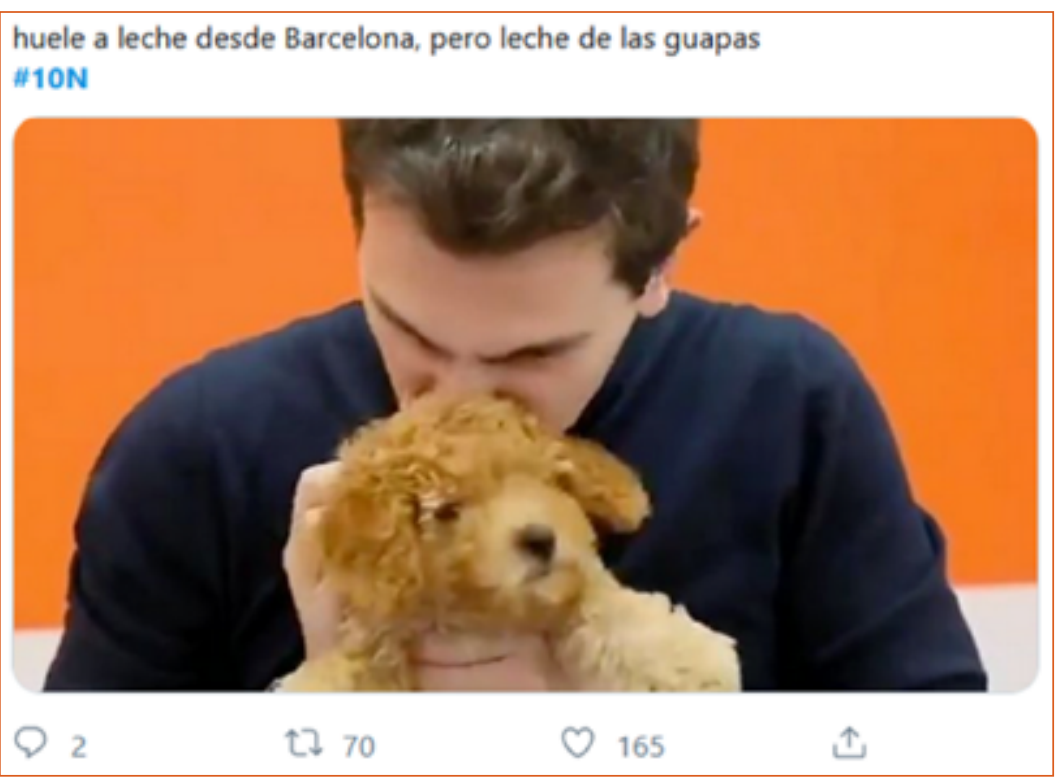

Figura 4 que se juega con la dilogía del sustantivo "leche", utilizado en el tuit con sentido figurado, al hacer alusión a la derrota electoral de este partido político (figura 4).

En el caso de los tuits de este tipo, aunque no poseen la estructura prototípica de los memes al uso -con el texto superpuesto sobre una imagen y destacado mediante una tipografía en color blanco-, hemos optado por tomarlos también en consideración, puesto que su contenido multimodal permite que texto e imagen contribuyan a conformar un mismo espacio discursivo, en el que el cuerpo del mensaje es complementado por una fotografía, tal y como sucede con los memes. Como ha puesto de manifiesto Yus (2019), cuando un internauta contempla un meme, debe llevar a cabo hipótesis inferenciales para interpretar tanto el texto como la imagen, atendiendo al rol conjunto que ambos ejercen.

En cuanto a la superestructura, algunos tuits pueden encuadrarse, aparentemente, en la dimensión descriptiva aunque, en realidad, orientan argumentativamente la interpretación del lector. Por ejemplo, parodiando el aspecto físico de la representante del Partido Socialista en uno de los debates (figura 5).

Algo similar se observa en la Figura 6, en la que el texto responde a una superestructura narrativa, pero gracias a la imagen puede advertirse la intencionalidad del autor del meme, lamentándose por el elevado número de votos obtenidos por Vox en la comunidad autónoma de Murcia.

Además, hay memes que responden a una secuencia dialogal-conversacional, aunque estos son los menos frecuentes (figura 7).

Los dos memes anteriores se publican en respuesta al tuit de otro internauta (Fig. 8), que se vanagloriaba por el hecho de que Vox no hubiera obtenido ningún escaño en Galicia, por tanto, podrían considerarse intervenciones reactivas-adviértase también cómo las 
imágenes confieren al tuit un carácter épico, otra muestra de "discurso pseudopolítico" (Gallardo y Enguix, 2016: 101), sustentado en la emoción- (figura 8).

Por otra parte, algunos memes podrían encuadrarse entre los tipos de texto en los que se

\section{Adriana Lastra en el \#Debatea7RTVE}

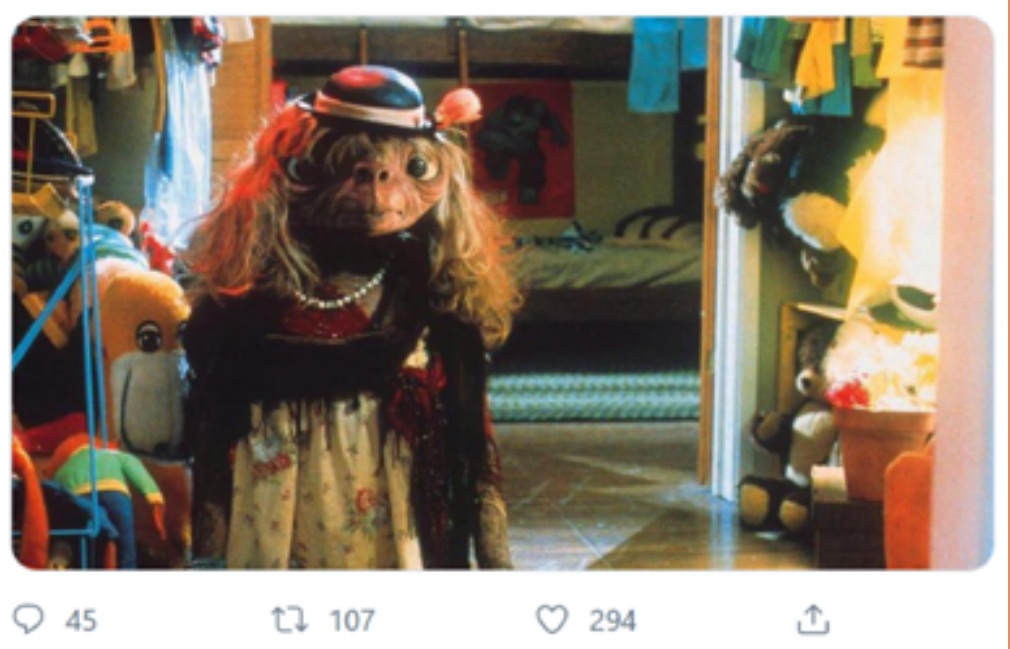

Figura 5

Mientras tanto aquí en Murcia... \#Envidialnsana

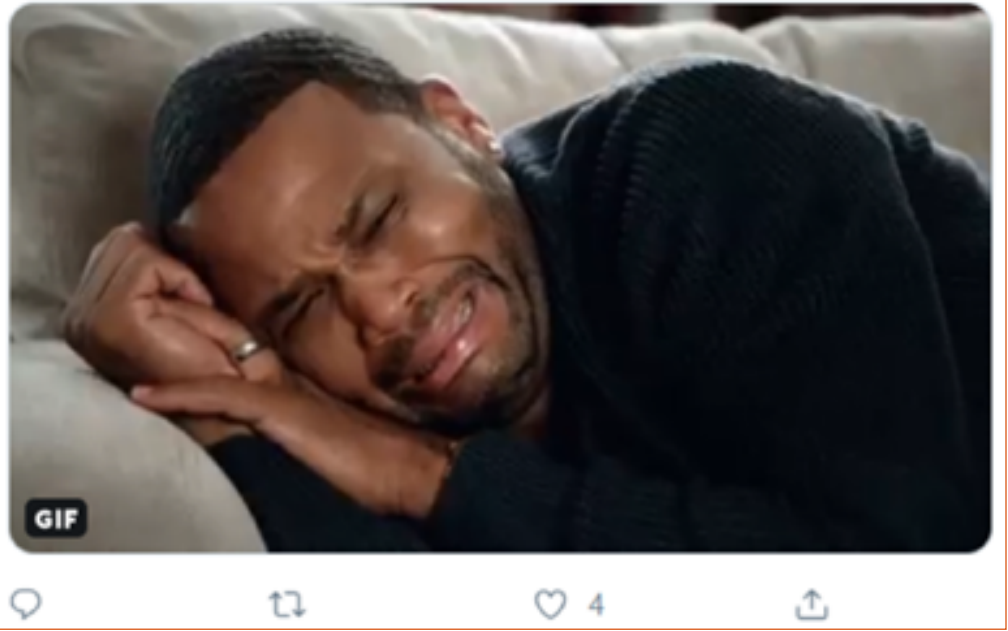

Figura 6

- YA, PERO AHI TENÉIS AL PP.

- VERÉIS A VOX EN LAS AUTONÓMICAS COMO ENTRA.

- FRANCO ERA GALLEGO, ¿SAES?

- LLEVÁIS DESDE FRAGA VOTANDO A LA DERECH.

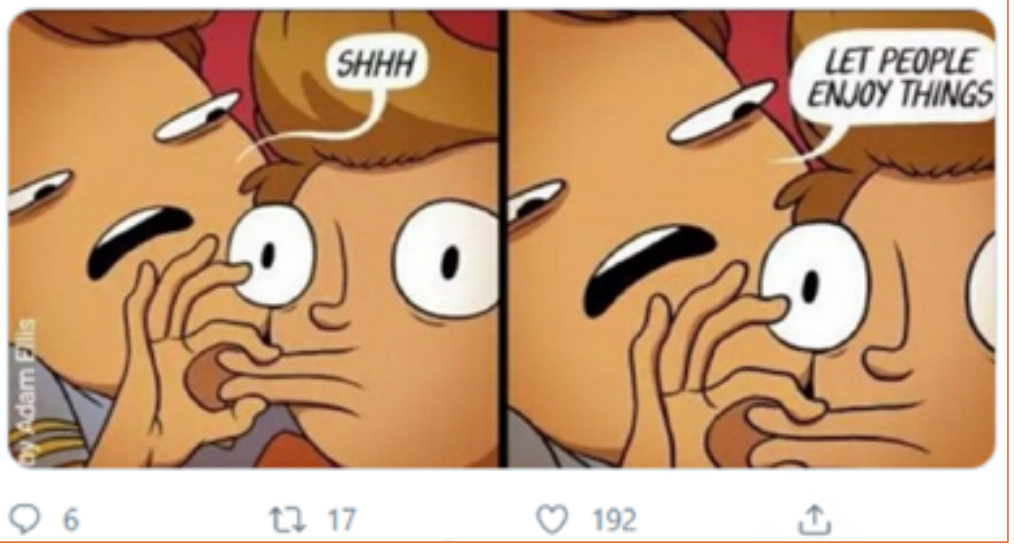

Figura 7 da una secuencia "explicativaexpositiva" (Adam, 1987: 54) tras la que, en realidad, subyace una argumentación clara, como ocurre en la Figura 9.

Otro aspecto del encuadre textual tiene que ver con la estructura informativa. Por ejemplo, en algunos memes analizados, el hashtag adopta en el cuerpo del mensaje la función informativa de soporte (Gutiérrez Ordóñez, 1997: 21). Esto es lo que sucede, por ejemplo, con \#YoVoto en la Figura 10, en la que las etiquetas no solo ejercen la función de metadato explícito que se integra en el tuit para ampliar su significado potencial al enlazarlo con otros mensajes (Zappavigna, 2011), sino que desempeñan, además, funciones sintagmáticas y se encuentran perfectamente integradas en la estructura oracional del texto -puede advertirse aquí también otra manifiestación de discurso pseudopolítico, sustentado exclusivamente en la imagen de los líderes de los distintos partidos del espectro político de la derecha- (figura 10).

Como explica Menna (2012: 49), el signo \# puede considerarse un "elemento semiótico relevante", que establece relaciones sintagmáticas con el resto de los constituyentes del tuit. Véase, asimismo, cómo al situar \#YoVoto en posición inicial se está destacando la "incitación a hacer" (Charaudeau, 2012: 127) que 


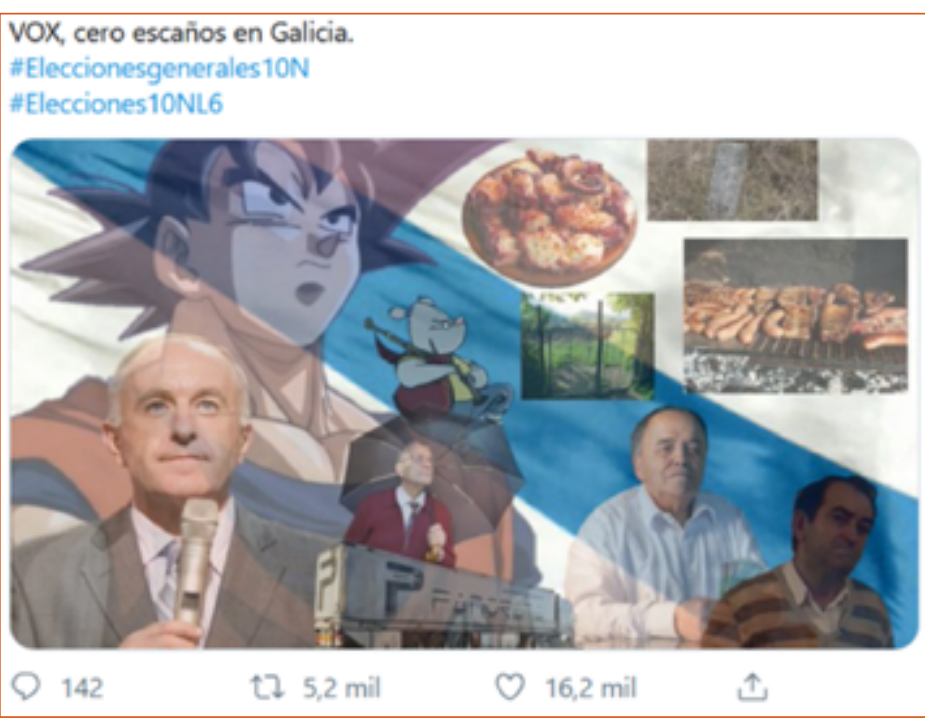

Figura 8

Entre bomberos no se pisan la manguera. Pedro Sánchez, de esta manera le agradece a @Vox los servicios prestados en la campaña \#10N.

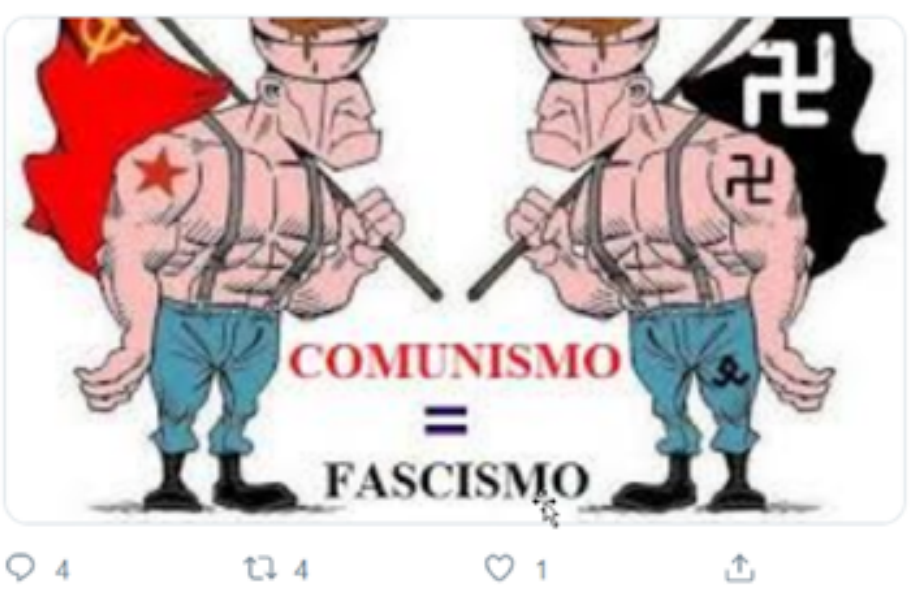

Figura 9

\#YoVoto porque en estas \#Elecciones10N no llegue "La noche eterna".

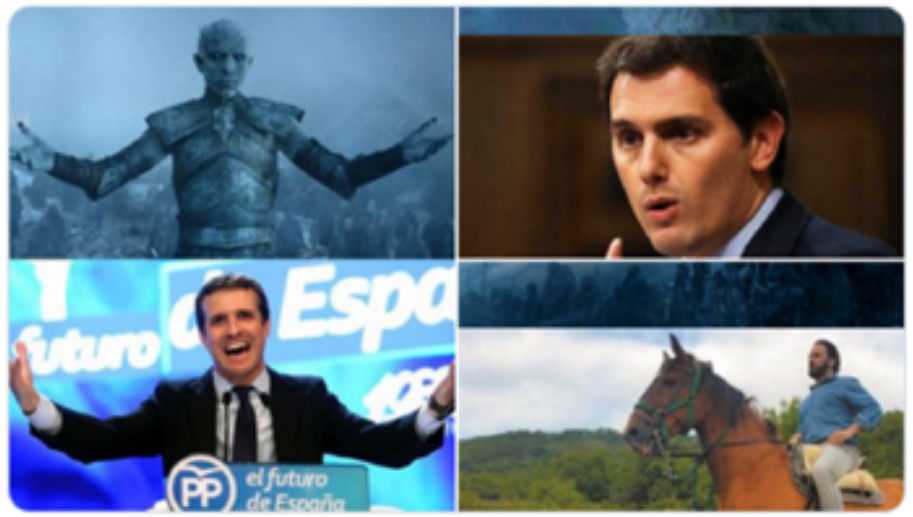

5:49 p. m. - 10 nov. 2019 - Twitter for iPhone

Figura 10 este hashtag conlleva. Y es que, según pusimos de manifiesto en Mancera y Pano (2015: 63), "las etiquetas no solo se convierten en mecanismos para contribuir a la difusión del mensaje a modo de eslogan perdurable", ya que también pueden insertarse en el enunciado con funciones sintácticas específicas y como marcas de la enunciación. Así, en la Figura 11, la etiqueta \#L6NPedroSánchez permite contextualizar el meme, pues solo gracias a ella el lector será capaz de interpretar que con el gif de Homer Simpson se está aludiendo al papel desempeñado por el presentador del programa de televisión La Sexta Noche al entrevistar al presidente del Gobierno, criticando su actitud excesivamente complaciente con el político (Figura 11).

Como puede apreciarse, en los memes anteriores existe una interdependencia entre texto e imagen, de manera que el uno no puede entenderse sin la presencia del otro. Incluso podría decirse, en el siguiente ejemplo (Figura 12), que la imagen es la que aporta la información que sustenta -la victoria de Vox, cuyo color simbólico es el verde, en Murciala argumentación explicitada en el texto del tuit -adviértase también cómo el complemento indirecto "a Murcia" experimenta el relieve focal al situarlo en posición inicial, con la consiguiente presencia del clítico redundante- (Figura 12).

Y en el caso de la Figura 13, el texto del tuit se presenta como una supuesta intervención reactiva coorientada con la argumentación subyacente en la "imagen macro" del meme.

En cuanto a los temas sobre los que versan estos mensajes, para su análisis hemos seguido la clasificación de Patterson (1980) -cit. en Villar (en prensa)-, que distingue entre policy issues, political issues, campaign issues y personal issues. En la primera de estas categorías se enmarcan aquellos que tienen que ver, por ejemplo, 
No falla ...

\#L6NPedroSánchez

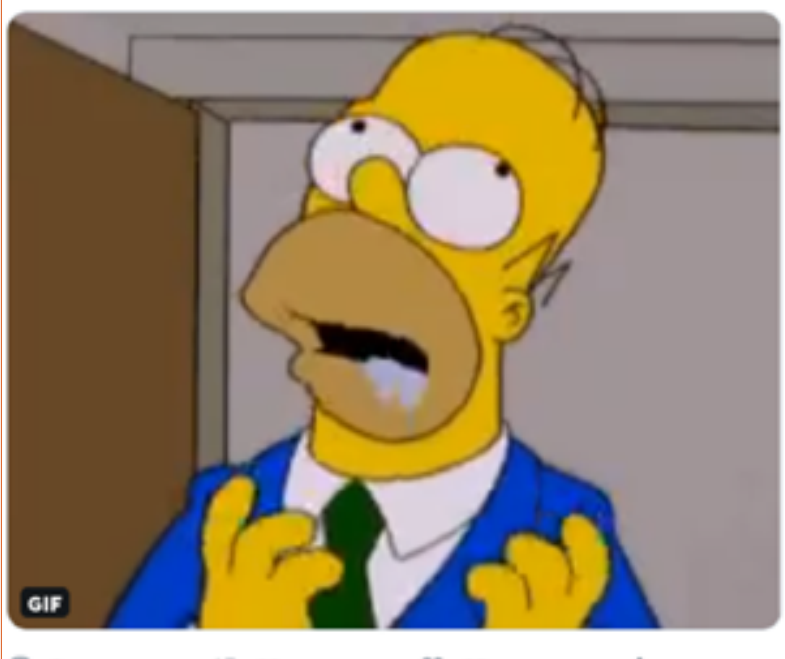

Figura 11

Totalmente de acuerdo..... y está hoy el dia para no salir de casa pero no pienso dar ni un paso atrás. Tiempos pasados,nunca

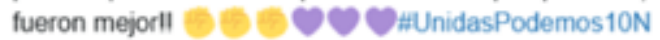
\#Elecciones $10 \mathrm{~N}$

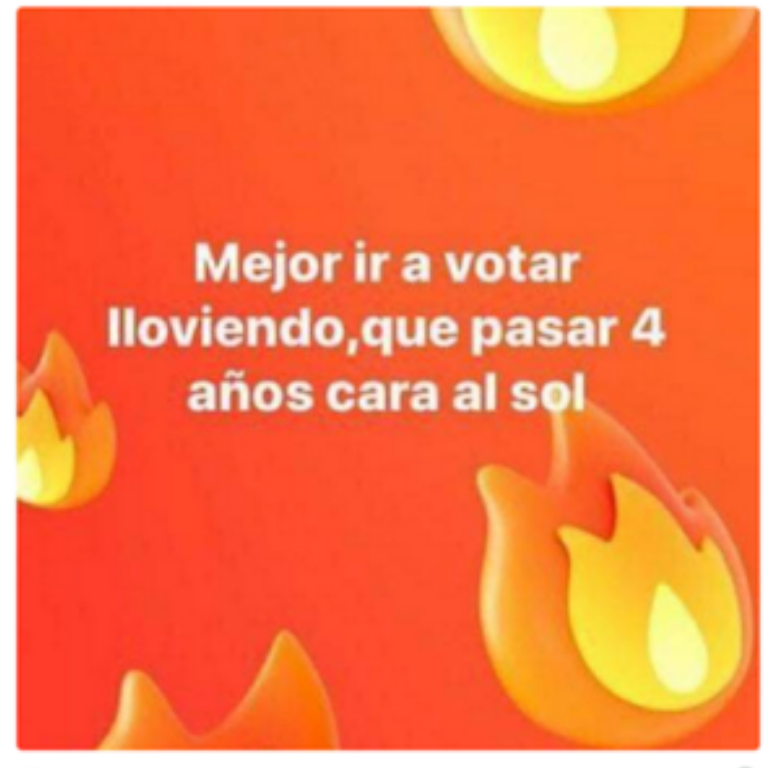

O 3 19:02-10 nov 2019

Figura 13

\#Elecciones10NL6 \#EleccionesNoviembre2019

Si hombres, elfos, enanos y hobbies fueron capaces de montar la comunidad del anillo, tampoco creo yo que sea tan dificil pactar para formar gobierno.

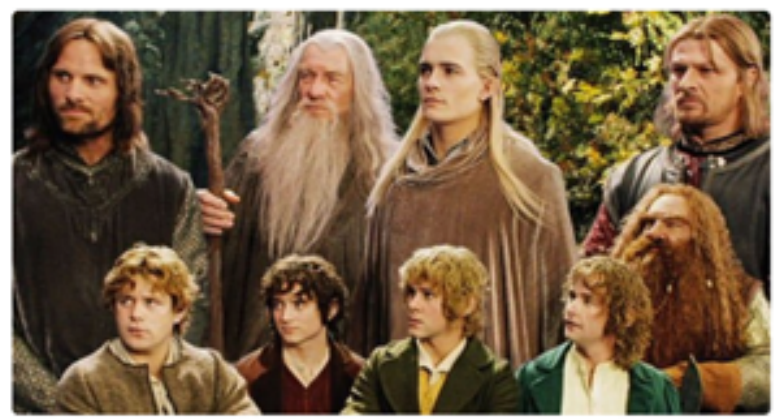

O $97819: 56$ - 10 nov. 2019

Figura 14
A Murcia le damos la Independencia mañana mismo.

\#eleccionesgenerales $10 \mathrm{~N}$

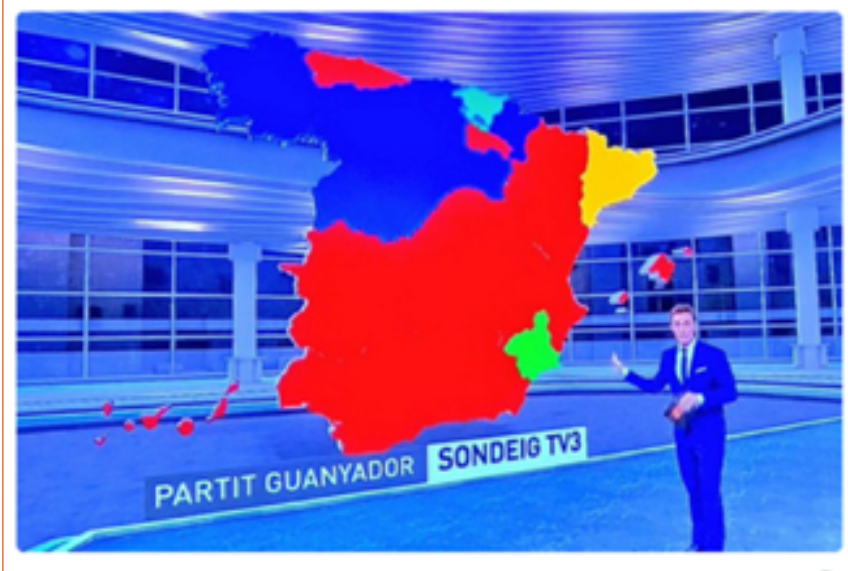

O 1.364 23.02 - 10 nov. 2019

Figura 12

con la política económica, la política social y la política territorial. Curiosamente, ninguno de los que conforman el más de centenar de memes de nuestro corpus contiene algún aspecto que pudiera encuadrarlo entre los policy issues. Bajo el marbete de political issues se integran aquellos mensajes que guardan relación con la ideología de los distintos partidos políticos, así como con las vinculaciones entre estos y la sociedad civil, - las alianzas post-electorales. A esta última cuestión alude el siguiente tuit (Figura 14), cuyo autor pone de manifiesto la demanda de una parte considerable de la sociedad española hacia los políticos, para lograr pactos que permitan la gobernabilidad del país.

A modo de réplica a este mensaje, otro internauta responde haciendo uso del siguiente meme (Figura 15), correspondiente a la serie de los calificados como "meme de Boromir", en el que el texto puede interpretarse como un enunciado de discurso referido que se atribuye a este personaje de la conocida novela de J. R. R. Tolkien, encarnado por el actor Sean Bean cuya imagen figura en el tuit- en la trilogía cinematográfica de Peter Jackson. De acuerdo con Shifman (2013), aunque en teoría los elementos retóricos, temáticosy enunciativos utilizables para la elaboración de un meme son infinitos, la realidad es que los usuarios se sirven de un número sorprendentemente pequeño de plantillas. Sin embargo, según 


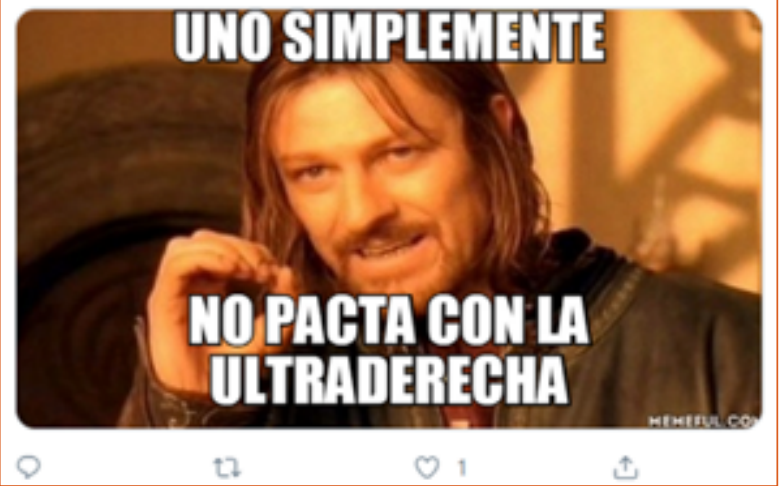

Figura 15

POR FAVOR «VotaPorFavor

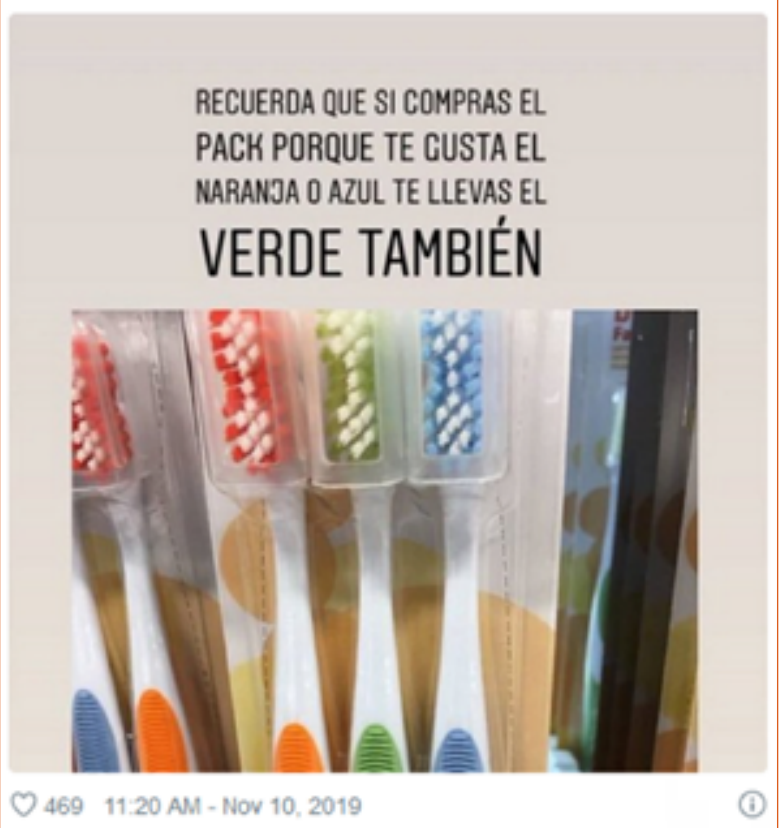

Figura 16

Seria muy bonito que Malú tuviera la otra mitad del adoquin. \#DebateElectoral \#Amor

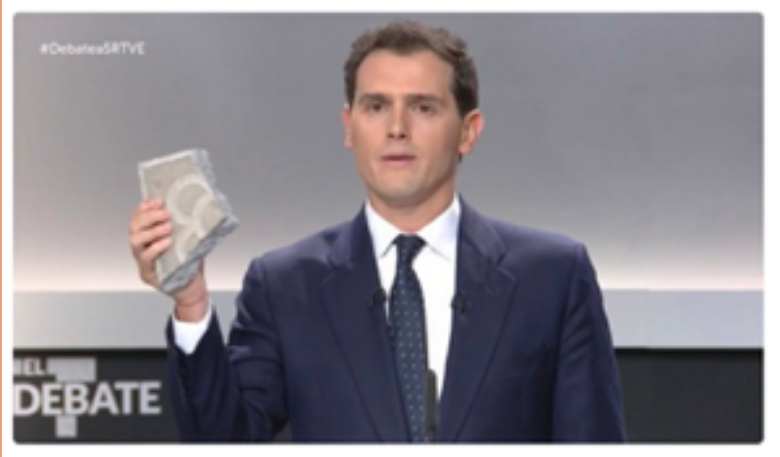

Figura 17
Siri (2016: 19), tal aparente "rigidez" puede poseer una importante función social: "Crear una sensación de comunidad en un mundo fragmentado". Por ejemplo, el enlace que adjuntamos en la siguiente nota al pie permite acceder a una recopilación de "memes de Boromir", caracterizados por la imagen de dicho personaje y el texto "Uno simplemente no...". Como explica Yus (en prensa), un meme puede formar parte de una serie de memes con los que comparte determinadas características $\mathrm{y}$, precisamente, su efecto humorístico se obtiene del reconocimiento de dichas cualidades por parte de los internautas, lo que implica un conjunto de conocimientos compartidos. En este caso, la mención a "la ultraderecha" -referencia ideológica que aporta una razón más para encuadrar este mensaje entre los political issues, además de la alusión a las alianzas post-electorales- conlleva una implicatura sobre Vox.

Al igual que sucede en este otro tuit (Figura 16), con el que se pretende movilizar a los internautas para que acudan a las urnas, pero advirtiéndoles del supuesto pacto entre Ciudadanos -“el naranja"-, Partido Popular -"el azul"- y Vox -"el verde"-.

Existen también algunos memes cuyo tema corresponde a los llamados personal issues, como el mostrado en la Figura 17, en el que se alude a la relación sentimental entre el líder de Ciudadanosyuna conocida cantante-denuevo, otra muestra de discurso pseudopolítico-.

Sin embargo, la mayoría de los memes de nuestro corpus se pueden integrar en lo que Patterson (1980) identifica como campaign issues. Así, algunos hacen alusión a los sondeos electorales. Por ejemplo, en la Figura 18 un internauta se sirve de la metáfora de las berenjenas, utilizada para hacer referencia al partido que ha adoptado el morado como color simbólico en el "mercado andorrano".

Con esta denominación se conoce a una conocida encuesta hecha pública por el Periòdic d'Andorra, de la que se hicieron eco numerosos medios de comunicación durante la jornada electoral. Dada la prohibición -existente en la legislación española desde 1985- de publicar cualquier estudio demoscópico cinco días antes de los comicios, desde hace algunos años, este diario viene publicando un sondeo sobre las 
intenciones de voto de la sociedad española "camuflándolas" tras los supuestos precios alcanzados en el mercado andorrano por productos como las rosas, el agua, el brócoli, la berenjena o las naranjas. También entre los campaign issues se incluyen las referencias a la configuración de las listas electorales (Fig. 19), así como a cualquier evento que tenga que ver con la campaña electoral, como los debates -por ejemplo, en la Figura

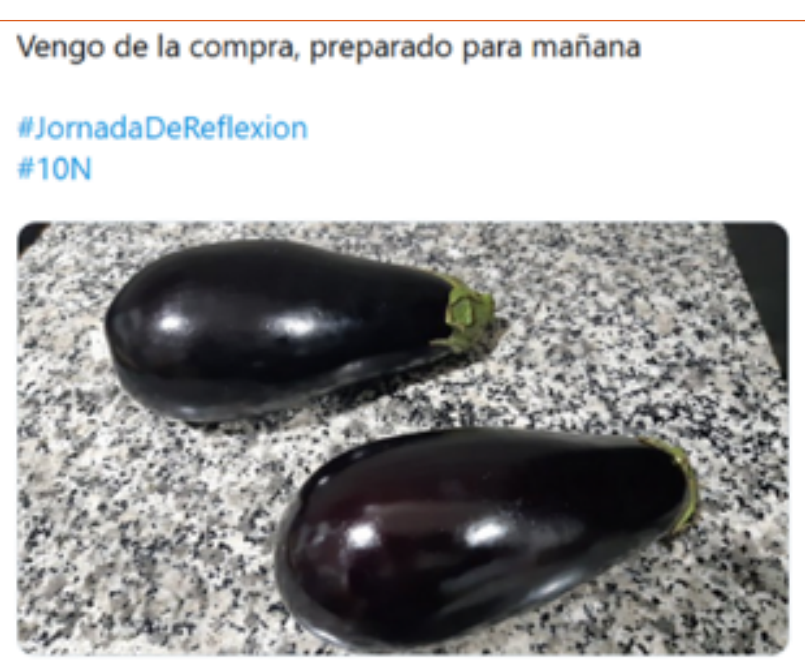

939 a. m. 9 nov. 2019 - Twitter for Androils

Figura 18

Yo fijo jajajajaja

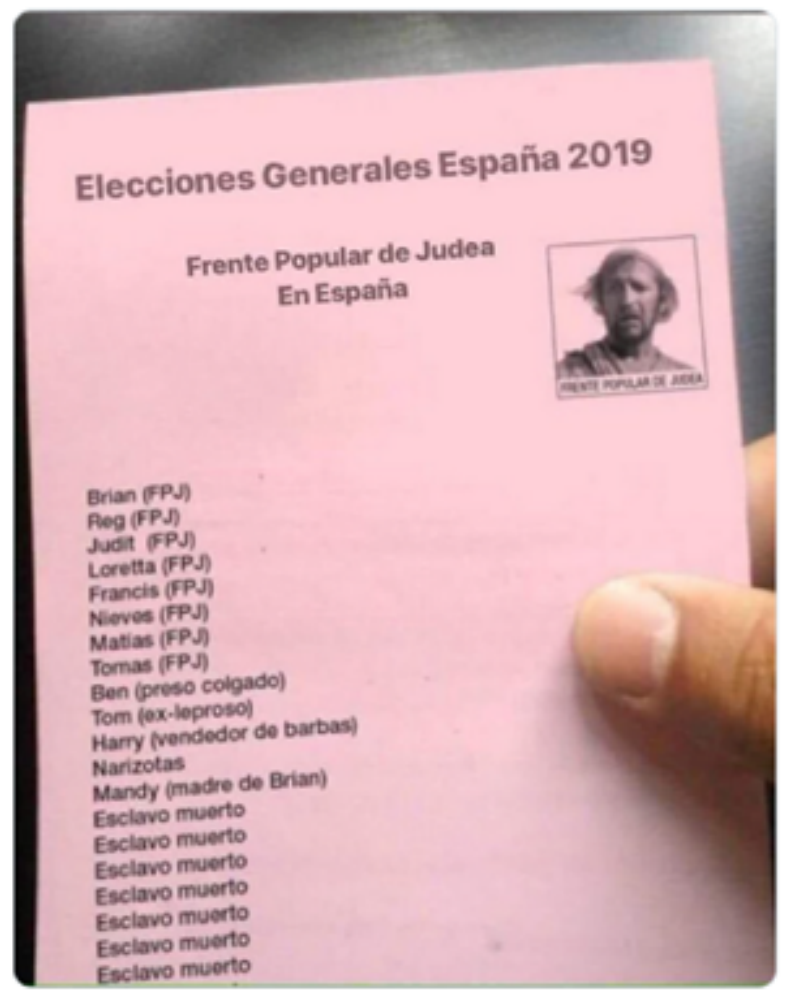

Figura 19 20 se parodia el gesto de Albert Rivera, al exhibir un adoquín en el transcurso de un debate, para criticar los violentos ataques hacia la policía por parte de los radicales violentos en Cataluña-, o las entrevistas, como puede apreciarse en la Figura 21, en la que la etiqueta \#L6NPedroSanchez es la que permite contextualizarlo, al encuadrar su valoración como reacción a una de las promesas electorales formuladas por el presidente del gobierno en funciones, durante una entrevista emitida por el programa La Sexta Noche.

Por otra parte, el encuadre enunciativo tiene que ver con las manifestaciones de la intención comunicativa del sujeto enunciador en su "acto individual de apropiación de la lengua" (Benveniste, 1971: 176). De acuerdo con la clasificación de Gallardo (en prensa) en la que se sustenta nuestro estudio, tres son los elementos "cuya selección resulta especialmente estratégica para la elaboración del texto": el acto de habla ilocutivo -que concierne al tipo de acción que el emisor pretende realizar por medio de su mensaje-, el acto de habla proposicional -manifestado en la selección léxica- y la actancialidad vinculada con el reparto de la acción y su responsabilidad en el ámbito extraverbal-.

En los tuits que conforman nuestro corpus podemos encontrar numerosos actos de habla en los que aparentemente se hace uso de una ilocutividad representativa, al expresar un estado de cosas como si estuviera dotado de valor veritativo, algo que la imagen del meme se encarga de desmentir, tal y como puede apreciarse en la Figura 22.

Según la Teoría semántica del humor basada en guiones (Raskin, 1985), para poder considerar un texto como humorístico deben advertirse en él, al menos, dos guiones diferentes que se oponen entre sí a la manera de una relación antonímica, superponiéndose de forma parcial o total. Por ejemplo, en la Figura 23, el humor se sustenta en la incongruencia entre el guion "informativo" evocado por el texto -que se 
-...Y con esta nueva propuesta y este material Alquímico, propongo crear una nueva Ley del Intercambio Equivalente en España para todos los alquimistas Espańoles" "DebateElectoral "Debatea7RTVE "Rivera "debateaSRTVE

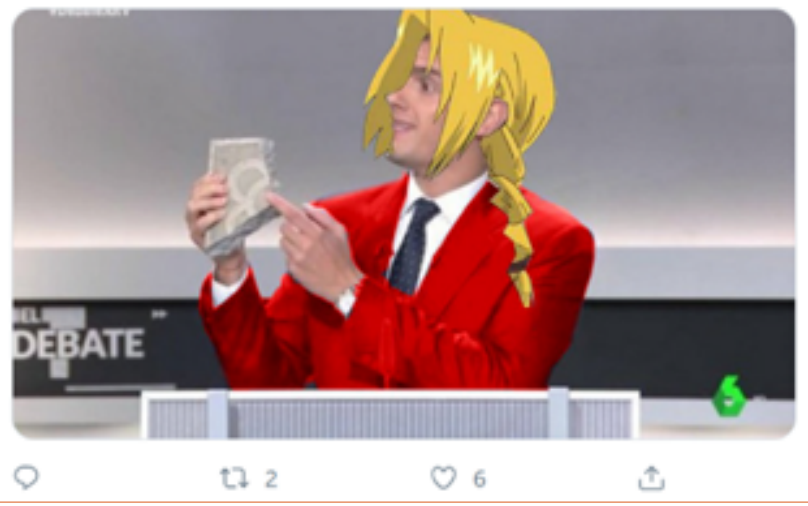

Figura 20

En la televisión anunciando los resultados \#eleccionesgenerales $10 \mathrm{~N}$

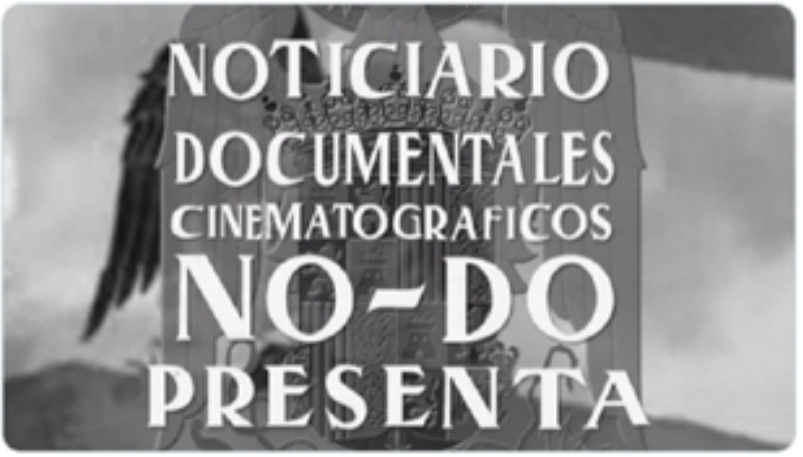

$10-56$ p. m. 10 nov. 2019 - Twitter Web App

Figura 22

\#Elecciones $10 \mathrm{~N}$

Hoy, programación especial por la Fiesta de la Democracia:

A las 9, apertura de colegios electorales

A las 14 , conoceremos el primer dato de participación

A las 18, el especial 'Democracia Consolidada'

A las 20 , cierre de colegios

A las 23, especial ' Y Ahora Qué'

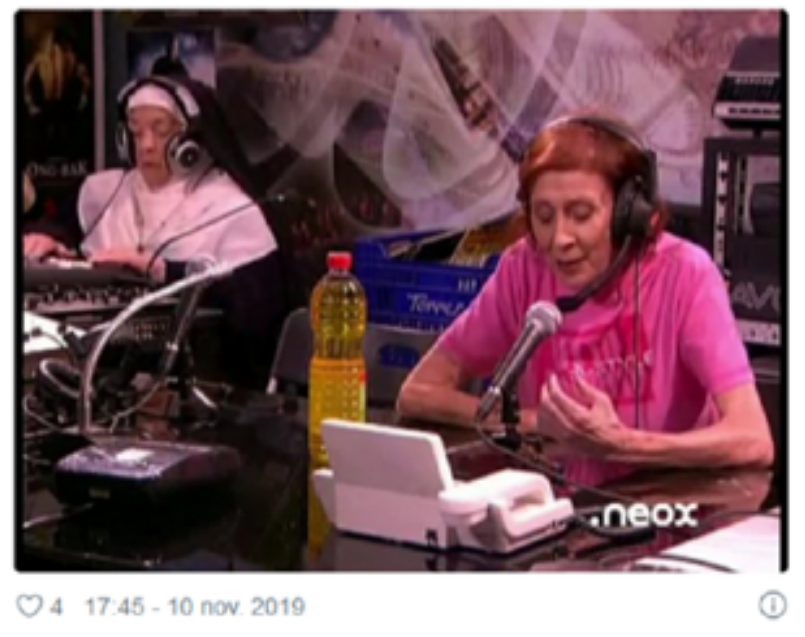

Figura 23
No se cual de estos emoticonos 2.2 es mejor para cuando el Presidente de Gobierno dice que una de sus primeras medidas será la revalorización de las pensiones delante de tres periodistas y nadie le pregunta por la mochila austriaca \#L6NPedroSanchez

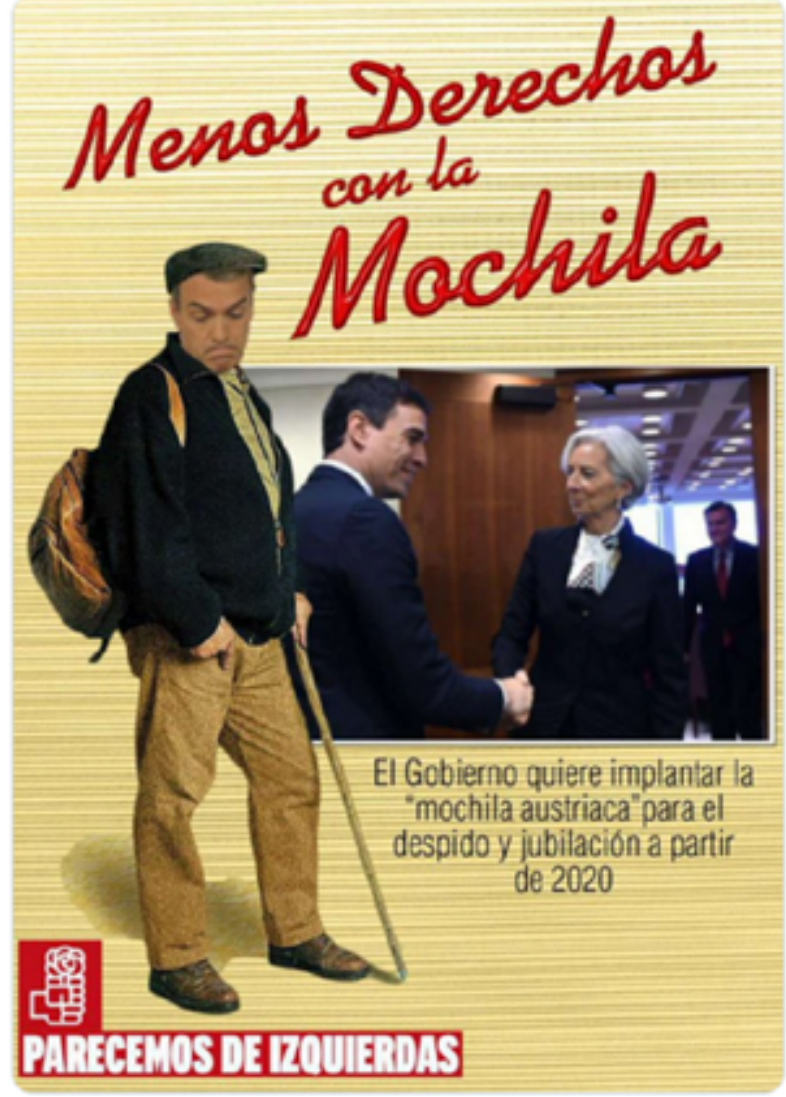

10.31 p. m. 2 nov. 2019 . Toitter Web App

Figura 21

"Debatea7RTVE Emocionante minuto de oro de lrene Montero plantando cara a uno de los hombres más poderosos del pais.

Irene me represent.

Tienes mi voto. 66

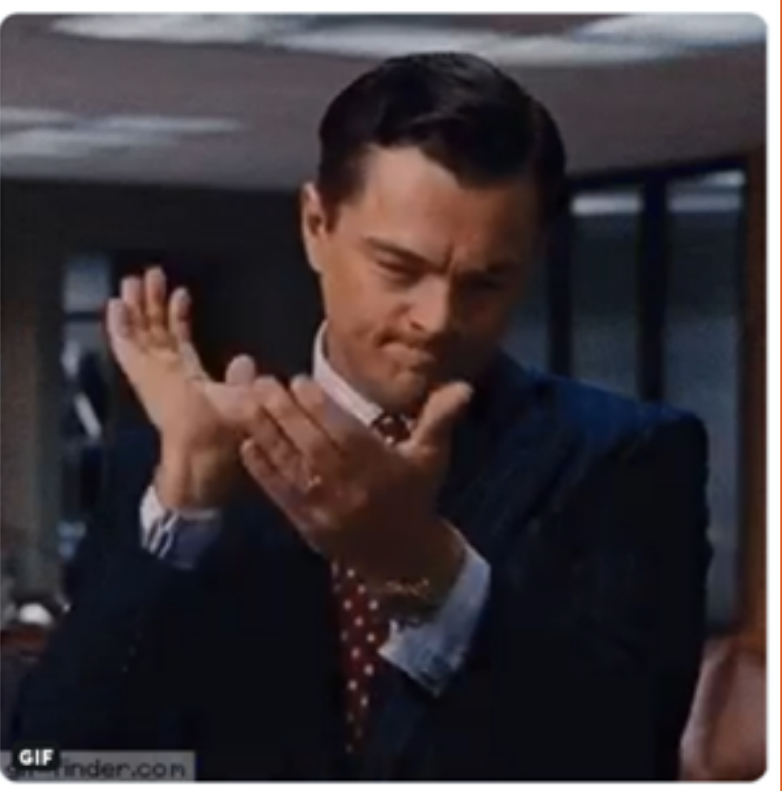

Figura 24 
asemeja al anuncio de la programación radiofónica de cualquier emisora- y el evocado por la imagen -una escena de la comedia televisiva Aquí no hay quien viva-, que permite al lector inferir fácilmente a quién cabe atribuir la actancialidad de los actos de habla proferidos, y justifica la selección léxica valorativa de los sintagmas nominales "Fiesta de la Democracia" y “Democracia Consolidada" o el grupo conjuntivo "Y Ahora Qué".

Si aplicamos la clasificación del discurso político llevada a cabo por Benoit (1999) cit. en Villar (en prensa) -según la cual en esta tipología textual pueden predominar el ataque, la defensa o la aclamación de un candidato o un partido- al análisis del "discurso pseudopolítico" (Gallardo y Enguix, 2016) formulado por los internautas en los tuits que conforman nuestro corpus, además de ataques -como los que se advierten en la mayor parte de los memes anteriores-, podemos identificar algunos ejemplos de discurso de "aclamación" de los líderes políticos, en los que se hace uso de un léxico de carácter valorativo, como el adjetivo "emocionante" o la locución verbal "plantar cara" en la Figura 24, en la que se hace referencia a una afirmación de Irene Montero dirigida contra el empresario Florentino Pérez.

Por otra parte, para movilizar a los internautas del espectro ideológico de la izquierda, se formulan actos de habla compromisivos que les advierten de la posibilidad de que la derecha vuelva a gobernar (Figura 25).

Un tuit al que responde otro internauta en la Figura 26 con un enunciado en mayúsculas -lo que en internet suele interpretarse como una aserción intensificada-, en el que la actancialidad predicativa se hace recaer sobre el pronombre de tercera persona "ellos", que tiene como referente a los periodistas y políticos que aparecen en las fotografías que acompañan al texto.

Obviamente, tanto en este meme como en el anterior (Figura 25) -correspondientes ambos a la categoría de los basados en una remixed image, en la clasificación de Milner (2012) que mencionábamos supra-, subyace la ilocutividad de expresividad negativa hacia las personalidades a las que se alude.

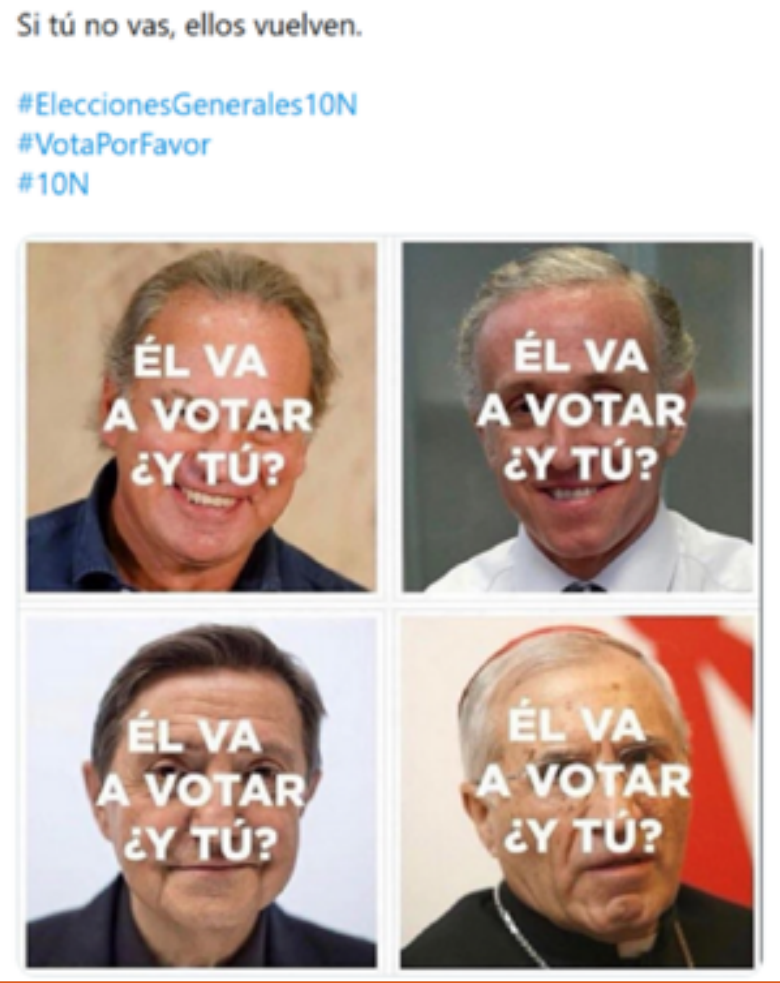

Figura 25

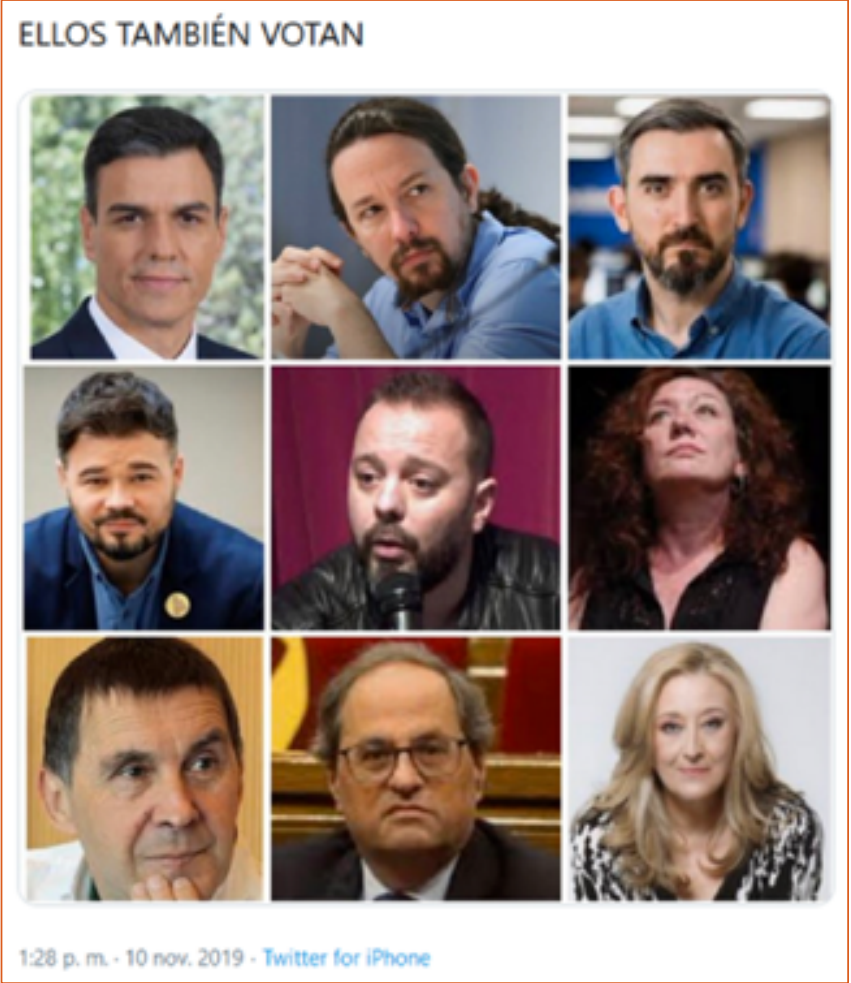

Figura 26 
Por último, podemos encontrar también en el corpus analizado memes en los que se hace uso de la ilocutividad directiva, para instar a otros internautas a acudir a las urnas. Véase cómo en la Figura 27 la actancialidad recae sobre los votantes, a los que se apela haciendo uso de la segunda persona del singular.

El tercer tipo de encuadre en la clasificación de Gallardo (2014) es el que tiene que ver con los mecanismos lingüísticos de atribución discursiva determinados por la consideración del enunciatario al que se dirige el mensaje. Así, algunos memes surgen en virtud de una "estrategia de alineamiento" (Stivers, 2008), al publicarse a modo de réplica de un mensaje previo. Por ejemplo, al tuit que presentábamos en la Figura 24, en el que un internauta elogia a Irene Montero por su participación en el debate de Radio Televisión Española (RTVE) y manifiesta explícitamente la intención de otorgarle su voto mediante un enunciado en el que apela a la candidata de Podemos haciendo uso de la segunda persona del singular -“Tienes mi voto"- responde otro internauta con el siguiente meme (Figura 28).

Véase el empleo que se hace del marcador discursivo "pues", identificado en la clasificación de Martín Zorraquino y Portolés (1999) como un comentador, ya que se caracteriza por introducir un nuevo comentario relacionado con el tópico del miembro discursivo precedente. En este caso, el referente al que se alude con el pronombre personal "lo" es el sustantivo "voto", mencionado en el enunciado con el que concluye el mensaje previo. Como explica Briz (1998: 174): "Pues presenta, unido a su valor fórico, un papel conversacional como marcador de respuesta, que enfatiza el acuerdo o el desacuerdo [...]. Pero además, como organizador de la materia discursiva, actúa en muchas ocasiones como límite de unidades de discurso o subunidades realzadas". Algo que permite interpretar este mensaje como una intervención reactiva respecto a lo asertado en el meme frente al que se presenta como respuesta. Ya en Pano y Mancera (2014a) pusimos de manifiesto cómo en este tipo de tuits publicados en un contexto político resulta frecuente encontrar numerosas intervenciones reactivas que vehiculan actos de evaluación negativa, para mostrar la disensión en la "contienda" electoral. En este caso, además, el internauta, en lugar de verbalizar las razones de su negativa a votar a Podemos, adjunta una conocida imagen en la que puede verse el torso del político Jesús Gil en un jacuzzi, sobre el que se ha superpuesto el rostro de Pablo Iglesias con lo que, implícitamente, se está dando a entender que su rechazo a otorgarle el voto se debe a que lo considera un corrupto. Jesús Gil fue alcalde de Marbella entre 1991 y 2002 e ingresó en prisión en diversas ocasiones, acusado de delitos de malversación de

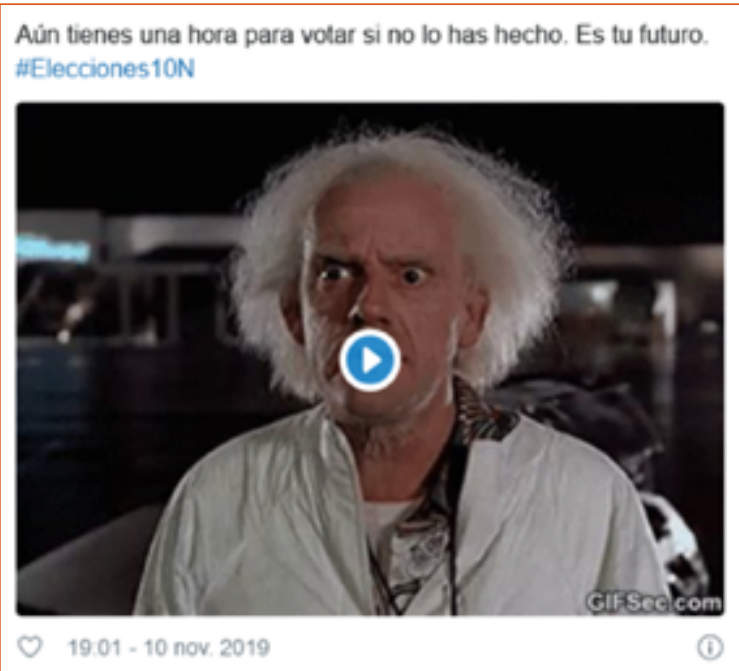

Figura 27 caudales públicos.

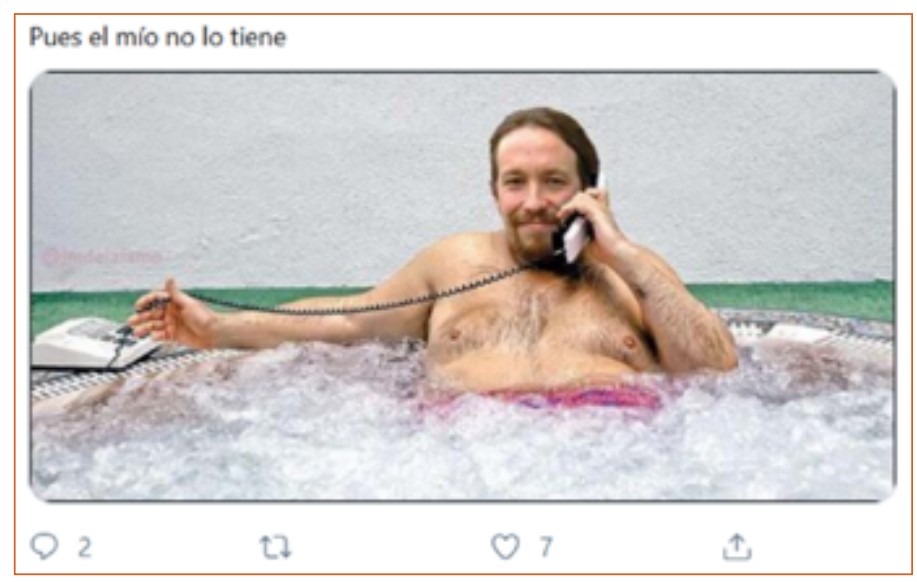

Figura 28 


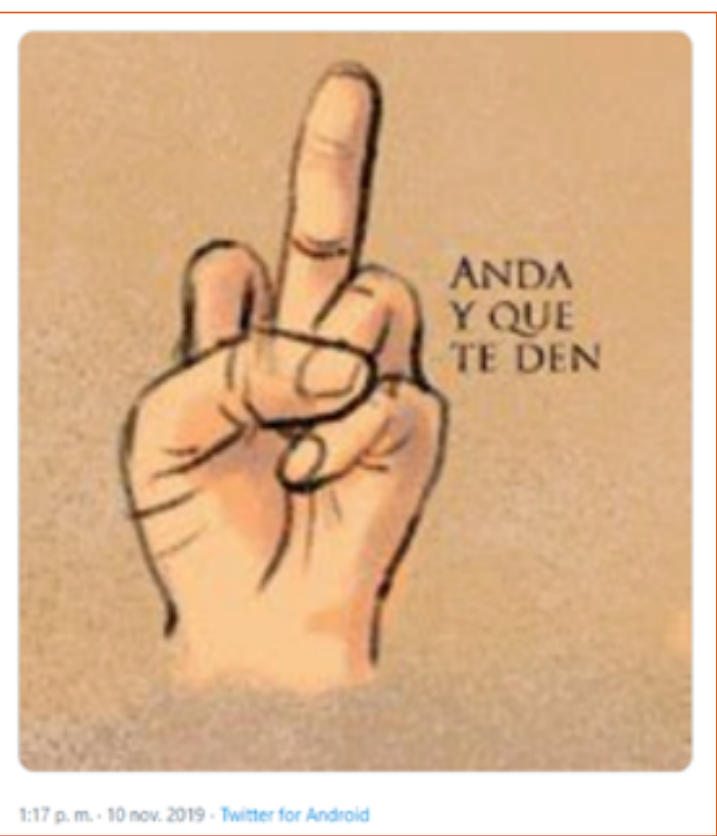

Figura 29

"¿Lo oyen?"
\#eleccionesgenerales $10 \mathrm{~N}$

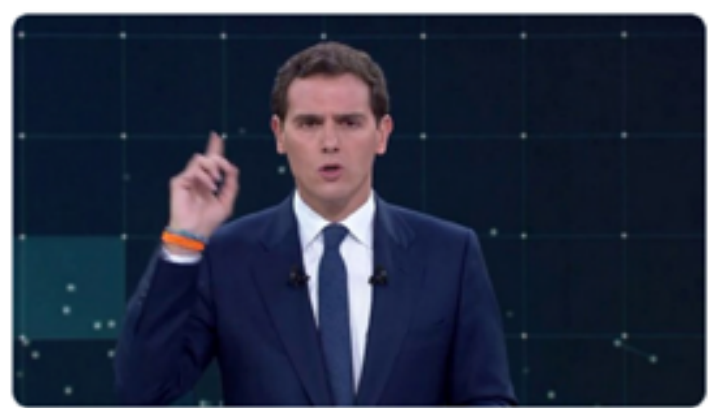

9209 p. m. 10 now. 2019 - Twitter for Androis

Figura 30

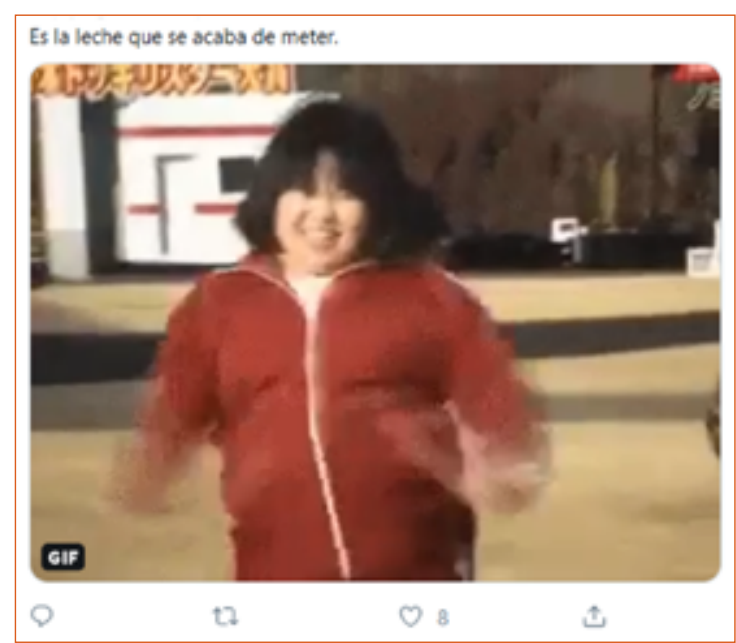

Figura 31
A veces, a modo de réplica, podemos encontrar incluso memes conformados por un acto directivo de carácter disfemístico, que se hace acompañar de una imagen que representa un gesto fácilmente interpretable, como el siguiente mensaje (Figura 29), con el que una internauta responde al tuit que presentábamos en la Figura 25, acerca del posible retorno de la derecha al gobierno.

También el dialogismo, “cuya realidad explícita en el texto la constituye el discurso 'referido' o discurso del 'otro', como posibilidad dialógica del locutor sujeto que refiere la narración (Voloshinov/Bajtín, 1929: 143)" (Gómez, 19831984:47) suele enmarcarse dentro del encuadre interactivo. Por ejemplo, resulta frecuente en los memes de nuestro corpus encontrar citas en estilo directo de las aserciones formuladas por los líderes políticos. Así, en la Figura 30 "resuenan" las palabras con las que Albert Rivera concluyó su intervención en el debate de Radio Televisión Española ${ }^{3}$ pero, al publicarse nada más conocerse los malos resultados electorales obtenidos por Ciudadanos, puede entenderse como una muestra de sarcasmo, verbalizado en este otro meme, que se presenta como intervención reactiva respecto al mensaje anterior (Figura 31).

En este caso, la intertextualidad del tuit puede advertirse fácilmente, ya que en él se reproduce una estructura sintáctica similar a la utilizada por Rivera en su discurso: "Es el silencio [...] que nos heló la sangre"; "es la leche que se acaba de meter".

Tales ejemplos constituyen una muestra de la afiliación ideológica de los discursos, un tipo de estrategia interactiva que "exige la existencia de dos líneas discursivas alternativas de las que pueda decirse que mantienen afiliación u oposición" (Gallardo, en prensa). En este caso,

3 Tales palabras suscitaron la hilaridad de los internautas en las redes sociales durante la misma noche del debate: "¿Lo oyen? Es el silencio. El silencio que nos heló la sangre a millones de españoles cuando los separatistas quisieron nuestro país en Catalunya. Pero es el silencio de una pareja triste que se mira a los ojos sabiendo que no podrá tener hijos, que no pueden tirar adelante una familia [...]" (El Periódico, 2019). 
ambos internautas parecen coincidir en su crítica hacia el líder de Ciudadanos, ya que los dos memes se muestran coorientados argumentativamente. En cambio, en los que presentábamos en la Figura 28 y en la Figura 29, la estrategia de encuadre se basaba en la discrepancia.

\section{Conclusiones}

De acuerdo con Grossi (2007), los medios de comunicación han dejado de constituir un mero canal a través del cual se difunden los mensajes políticos, para erigirse en verdaderas infraestructuras funcionales de la política. Según Castells (2009: 262), dos son los procesos clave que los convierte en "el espacio donde se crea poder": el establecimiento de la agenda (agenda setting) y las estrategias de encuadre (framing).

Sin embargo, como hemos tratado de demostrar en la presente investigación, al difundir determinados memes en las redes sociales, los internautas llevan a cabo también una serie de estrategias de encuadre, en un intento de concienciar a la opinión pública sobre la necesidad de acudir a votar -por ejemplo, haciendo uso del hashtag \#YoVoto-, o de mostrar su parecer acerca del comportamiento o las aseveraciones de los políticos en determinados actos de campaña (campaign issues) -como las intervenciones en entrevistas televisivas o en debates electorales- (Patterson, 1980).

La ausencia de memes que versen sobre policy issues en el corpus que hemos analizado -conformado por los textos de este tipo más difundidos en Twitter durante las elecciones generales celebradas en España en noviembre de 2019- confirma el planteamiento de Gallardo y Enguix (2016: 101), que han puesto de manifiesto la propagación masiva en las redes sociales de un "discurso pseudopolítico". Este se caracteriza por la desideologización de la ciudadanía, algo que se advierte también en nuestro corpus, en la escasez de memes que abordan political issues. Los argumentos lógicos han sido sustituidos por un discurso sustentado únicamente en la emoción, que lleva a recurrir a macroestrategias propias de la confrontación política, como la auto-presentación positiva de "nosotros" frente al relato negativo de "ellos" (Van Dijk, 2003: 43). Al mostrar a los líderes políticos, por ejemplo, en fotomontajes que los presentan como corruptos, o recurriendo a memes basados en la mezcla de distintas imágenes (remixed image), que comparan sus efigies con las de villanos cinematográficos. Como advierte Winckler (2019: 5), "las propiedades latentes de la imagen en su consideración aislada emergen y salen a la luz a partir del acto de 'montar' juntas imágenes que no lo estaban originalmente". Llegando incluso a proferir bias ad hominem con los que, supuestamente, tratan de denunciar las circunstancias que hacen que su posición resulte parcial y sospechosa (Walton, 1998) o, incluso, al equipararlos con personajes televisivos conocidos por su escaso coeficiente intelectual. Y es que la personalización de la política es otro de los rasgos del discurso pseudopolítico que se manifiesta en nuestro corpus, pues muchos de estos memes abordan personal issues, como el aspecto físico de un candidato o sus relaciones sentimentales.

Asimismo, la "espectacularización" (Gallardo y Enguix, 2016: 100) de la información difundida en los medios se advierte en la adopción de determinadas estrategias de encuadre enunciativo, como la que lleva a hacer uso de una ilocutividad representativa, al verbalizar un estado de cosas como si estuviera dotado de valor veritativo -simulando una cobertura mediática-, para desmentirlo a través de una imagen. Tal encuadre, basado en la intertextualidad, además de generar una incongruencia entre dos guiones (Raskin, 1985) con el fin de provocar la hilaridad, 
persigue que el enunciador y sus enunciatarios se alíen y se diviertan a costa de los individuos y las situaciones parodiadas (Pano y Mancera, 2014b). Algo que se manifiesta en el encuadre interactivo mediante la "estrategia de alineamiento" (Stivers, 2008: 31) y las frecuentes muestras de afiliación ideológica.

\section{Referencias}

Adam, J. M. (1987): “Typs de séquences textuales élémentaires”, en Pratiques, vol. 56, pp. 54-79.

Ballesteros Doncel, E. (2016): "Circulación de memes en WhatsApp: ambivalencias del humor desde la perspectiva de género", en Empiria. Revista de Metodología de Ciencias Sociales, vol. 35, pp. 21-45.

Benoit, W. L. (1999): Seeing spots: A functional analysis of presidential television advertisements, 1952-1996. Westport: Praeger.

Benveniste, E. (1971): Problemas de lingüística general I y II. México: Siglo XXI.

Blackmore, S. (1998): "Imitation and the definition of a meme", en Journal of Memetics, vol. 2 (2), pp. 1-15.

Blackmore, S. (1999): The Meme Machine. Oxford: Oxford University Press.

Blackmore, S. (2001): "Evolution and memes: The human brain as a selective imitation device", en Cybernetics and Systems, vol. 32 (1), pp. 225-255.

Briz Gómez, A. (1998): El español coloquial en la conversación: Esbozo de pragmagramática. Barcelona: Ariel.

Burucúa, J. E. (2007): La imagen y la risa. Cáceres: Periferia.

Castells, M. (2009): Comunicación y poder. Madrid: Alianza.

Centro de Investigaciones Sociológicas (2019): “Macrobarómetro de octubre de 2019. Preelectoral Elecciones Generales 2019 (Estudio no 3.263)". Disponible en: http:// www.cis.es/cis/export/sites/default/-Archivos/Marginales/3260_3279/3263/3263_ Estimacion.pdf [Consulta: 18 de marzo de 2020].

Charaudeau, P. (2012): "El discurso de la propaganda: un intento de tipologización". En: Shiro, M., Charaudeau, P. y Granato, L. (eds.): Los géneros discursivos desde múltiples perspectivas: teorías y análisis. Madrid/Frankfurt: Iberoamericana/Vervuert, pp. 125138.

Dawkins, R. (1979): El gen egoísta. Barcelona: Labor.

Dynel, M. (2016): “I has seen image macros!' Advice animal memes as visual-verbal jokes", en International Journal of Communication, vol. 10, pp. 660-688. Disponible en Internet: https://pdfs.semanticscholar.org/9d9b/cba859e3d74a343cd9e69e78fbe083236626. pdf [Consulta: 18 de marzo de 2020].

El Periódico (2019): "El "¿Lo oyen? Es el silencio" de Rivera se viraliza”, 23-04-2019. Disponible en: https://www.elperiodico.com/es/politica/20190423/oyen-silenciorivera-viral-7419496 [Consulta: 18 de marzo de 2020].

Elogia (2019): “Estudio Anual de Redes Sociales en España 2019”. Disponible en: https:// elogia.net/estudio-anual-redes-sociales-2019-en-espana/ [Consulta: 18 de marzo de 2020].

Feld, L. y Wilcox, N. (2008): Netroots rising. How a citizen army of bloggers and online activists is changing American politics. Westport, CT: Praeger Publishers. 
Forceville, C. (2014): "Relevance Theory as model for analyzing visual and multimodal communication". En: Machin, D. (ed.): Visual Communication. Berlín: Gruyter, pp. 5170.

Forceville, C. y B. Clark (2014): “Can pictures have explicatures?”, en Linguagem em (Dis) curso, vol. 14 (3), pp. 451-472.

Gal, N., L. Shifmany Z. Kampf(2015): “'It Gets Better': Internet memes and the construction of collective identity", en New Media \& Society, vol. 18 (8), pp. 1698-1714.

Gallardo Paúls, B. (2014): Usos políticos del lenguaje: Un discurso paradójico. Barcelona: Anthropos.

Gallardo Paúls, B. (en prensa): “Texto y comunicación: el encuadre y la eficacia textual”. En: Loureda, O. y Schrott, A. (coords.): Manual de Lingüística del Texto. Berlín: Gruyter.

Gallardo Paúls, B. y Enguix Oliver, S. (2016): Pseudopolítica: El discurso político en las redes sociales. Valencia: Dept Teoria dels Llenguatges i Ciències de la Comunicació-UV. Disponible en Internet: https://www.researchgate.net/publication/299284420_2016_ Pseudopolitica_el_discurso_politico_en_las_redes_sociales [Consulta: 18 de marzo de 2020].

Gómez, F. V. (1983-1984): “El concepto de 'dialoguismo' en Bajtín: La otra forma del diálogo renacentista", en Anuario de la Sociedad Española de Literatura General y Comparada, vol. 5, pp. 47-54.

Grossi, G. (2007): La opinión pública: Teoría del campo demoscópico. Madrid: Centro de Investigaciones Sociológicas.

Gutiérrez Ordoñez, S. (1997): Temas, remas, focos, tópicos y comentarios. Madrid: Arco/ Libros.

Kanai, A. (2016): "Sociality and classification: Reading gender, race, and class in a humorous meme", en Social Media + Society, vol. 2, pp. 1-12.

Lara, T. (2012): “Twitter y sus funciones comunicativas", Blog Tíscar.com. Disponible en Internet: http://tiscar.com/2012/03/11/twitter-y-sus-funciones-comunicativas

[Consulta: 18 de marzo de 2020].

Mancera Rueda, A. y Pano Alamán, A. (2013): El discurso político en Twitter. Barcelona: Anthropos.

Mancera Rueda, A. y Pano Alamán, A. (2015): "Valores sintáctico-discursivos de las etiquetas en Twitter", en Círculo de Lingüística Aplicada a la comunicación, vol. 64, pp. 5883. Disponible en Internet: https://revistas.ucm.es/index.php/CLAC/article/view/51278 [Consulta: 18 de marzo de 2020].

Mancera Rueda, A. y Pano Alamán, A. (en prensa): La opinión pública en la red: Análisis pragmático de la voz de los ciudadanos. Madrid/Frankfurt: Iberoamericana/Vervuert.

Marino, G. (2015): "Semiotics of spreadability: A systematic approach to Internet memes and virality", en Punctum. International Journal of Semiotics, vol. 1 (1), pp. 43-66.

Martín Zorraquino, M. A. y Portolés Lázaro, J. (1999): “Los marcadores del discurso". En: Bosque, I. y Demonte, V. (dirs.): Gramática descriptiva de la lengua española. Madrid: Espasa, pp. 4051-4213.

Mazzoleni, G. (2014): La comunicación política. Madrid, SPAIN: Difusora Larousse - Alianza Editorial.

Menna, L. (2012). “Nuevas formas de significación en red: el uso de las \#etiquetas en el 
movimiento 15M", en Estudios de Lingüística del Español, vol. 34. Disponible en Internet: http://elies.rediris.es/elies34/Tesina_L-Menna.pdf [Consulta: 18 de marzo de 2020].

Milner, R. M. (2012): The World Made Meme: Discourse and Identity in Participatory Media. Tesis doctoral inédita: Universidad de Kansas. Disponible en Internet: https:// kuscholarworks.ku.edu/handle/1808/10256 [Consulta: 18 de marzo de 2020].

Miltner, K. M. (2014): “There's no place for lulz on LOLCats': The role of genre, gender, and group identity in the interpretation and enjoyment of an Internet meme", en First Monday, vol. 19 (4). Disponible en Internet: https://journals.uic.edu/ojs/index.php/ fm/article/view/5391 [Consulta: 18 de marzo de 2020].

Morris, C. (1985): Fundamentos de la teoría de los signos. Barcelona: Paidós.

Pano Alamán, A. y Mancera Rueda, A. (2014a): “La 'conversación' en Twitter: las unidades discursivas y el uso de marcadores interactivos en los intercambios con parlamentarios españoles en esta red social", en Estudios de Lingüística del Español, vol. 35, pp. 243-277. Disponible en Internet: https://idus.us.es/xmlui/handle/11441/52721 [Consulta: 18 de marzo de 2020].

Pano Alamán, A. y Mancera Rueda, A. (2014b): “Identidades falsas en Twitter: la ironía y el humor verbal como mecanismos paródicos", en Discurso y Sociedad, vol. 8 (3), pp. 507-536. Disponible en Internet: http://www.dissoc.org/ediciones/v08n03/DS8(3) Pano\&Mancera.pdf [Consulta: 18 de marzo de 2020].

Patterson, T. (1980): The Mass Media Election. Nueva York: Praeger.

Pestarino, J. y Winckler, G. (2018): “Memes políticos: apropiabilidad digital en la web 2.0", en Artefacto visual, vol. 3 (4), pp. 2530-4119. Disponible en Internet: https://irudi. hypotheses.org/120 [Consulta: 18 de marzo de 2020].

Pérez Barber, V. (2010): El político en la Red Social. Alicante: Editorial Club Universitario.

Raskin, V. (1985): Semantic Mechanisms of Humor. Reidel: Dordrecht.

Rubio Núñez, R. (2009): “Quiero ser como Obama (me pido una red social)”, en Cuadernos de pensamiento político FAES, vol. 21, pp. 123-154.

Shifman, L. (2012): "An anatomy of a YouTube meme", en New Media \& Society, vol. 14(2), pp. 187-203. Disponible en Internet: https://www.semanticscholar.org/paper/An-anatomyof-a-YouTube-meme-Shifman/eb903acf8ee5107d442219e3bafecb995cad5452 [Consulta: 18 de marzo de 2020].

Shifman, L. (2013): Memes in Digital Culture. Boston: MIT Press.

Siri, L. (2016): "Memes en internet: el escándalo Snowden”, en Letra. Imagen. Sonido: Ciudad Mediatizada, vol. 16, pp. 16-39. Disponible en Internet: https://dialnet.unirioja. es/servlet/articulo?codigo=5837694 [Consulta: 18 de marzo de 2020].

Steimberg, O. (2013): Semióticas: Las semióticas de los géneros, de los estilos, de la transposición. Buenos Aires: Eterna Cadencia.

Stivers, T. (2008): “Stance, Alignment, and Affiliation During Storytelling: When Nodding Is a Token of Affiliation", en Research on Language and Social Interaction, vol. 41 (1), pp. 31-57. Disponible en Internet: https://www.researchgate.net/publication/237416816 Stance_Alignment_and_Affiliation_During_Storytelling_When_Nodding_Is_a_Token_of_ Affiliation [Consulta: 18 de marzo de 2020].

The Social Media Family (2020): “Estudio sobre los usuarios de Facebook, Twitter e Instagram en España". Disponible en: https://thesocialmediafamily.com/descargas/ 
[Consulta: 18 de marzo de 2020].

Van Dijk, T. A. (2003): Ideología y discurso. Barcelona: Gedisa.

Vélez Herrera, J. (2015): "Influyendo en el ciberespacio con humor: imemes y otros fenómenos", en Versión. Estudios de Comunicación y Política, vol. 35, pp. 130-146. Disponible en Internet: https://www.academia.edu/12495960/Influyendo_en_el_ ciberespacio_con_humor_imemes_y_otros_fen\%C3\%B3menos [Consulta: 18 de marzo de 2020].

Villar Hernández, P. (en prensa): "El discurso pseudopolítico y creativo de la segunda pantalla: \#EIDebateEnRTVE visto a través de sus prosumers".

Walton, D. N. (1998): Ad hominem arguments. Tuscaloosa: University of Alabama Press.

Wiggins,B.yBowers,B.(2015):"Memesasgenre:Astructurationalanalysisofthememescape”, en New Media \& Society, vol. 17 (11), pp. 1886-1906. Disponible en Internet: https:// journals.sagepub.com/doi/abs/10.1177/1461444814535194?journalCode=nmsa [Consulta: 18 de marzo de 2020].

Winckler, G. (2019): "Internet Memes: una relación visual contemporánea", en ASRI: Arte y sociedad. Revista de investigación, vol. 17, pp. 1-11. Disponible en Internet: https://www. eumed.net/rev/asri/17/internet-memes.pdf [Consulta: 18 de marzo de 2020].

Yus Ramos, F. (2018): "Identity-Related Issues in Meme Communication", en Internet Pragmatics, vol. 1 (1), pp. 113-133. Disponible en Internet: https://personal.ua.es/ francisco.yus/site/memesIP.pdf [Consulta: 18 de marzo de 2020].

Yus Ramos, F. (2019): “Multimodality in memes. A cyberpragmatic approach". En: BouFranch, P. y Garcés-Conejos Blitvich, P. (eds.): Analyzing Digital Discourse: New Insights and Future Directions. Cham: Palgrave Macmillan, pp. 105-131. Disponible en Internet: https://personal.ua.es/francisco.yus/site/multimodality.pdf [Consulta: 18 de marzo de 2020].

Yus Ramos, F. (en prensa): "Pragmatics of humour in memes in Spanish", en Spanish in Context, vol. 18 (2). Disponible en Internet: https://personal.ua.es/francisco.yus/site/ SiC.pdf [Consulta: 18 de marzo de 2020].

Zappavigna, M. (2011): "Ambient affiliation: a linguistic perspective on Twitter", en New Media Society, vol.13(5), pp. 788-806. Disponible en Internet: https://www.researchgate. net/publication/258173684_Ambient_affiliation_A_linguistic_perspective_on_Twitter [Consulta: 18 de marzo de 2020].

20 Minutos (2019): "Rivera presenta su arma secreta para el debate: "Aún huele a leche"',', 04-11-2019. Disponible en: https://www.20minutos.es/videos/nacional/4040574rivera-presenta-su-arma-secreta-para-el-debate-aun-huele-a-leche/ [Consulta: 18 de marzo de 2020]. 